\title{
NEOLIBERAL IMPERIALISM AND PAN-AFRICAN RESISTANCE
}

\author{
Niels S. C. Hahn \\ Department of Development Studies \\ School of Oriental and African Studies \\ University of London \\ nsc.hahn@gmail.com
}

\begin{abstract}
Neoliberalism has in the past three decades had a tremendous impact on both thought and practice throughout most of the world, and has dominated international development since the early 1980s. Although neoliberalism presents itself as modern and progressive, it is argued that the underlying ideologies and power agendas have their origins in the political debates of the eighteenth century and earlier. Through an analysis of neoliberalism from a world-historical and global perspective, indications are seen that the international development agenda has more to do with political and economic interests than with benevolent pro-poor development. This leads to the debate about redistribution of resources and State-led Development versus Free-market Development, which is inextricable from the discussion of Liberal Democratic Peace Theory versus Realism. From this perspective it is argued that the notion of democratic peace is used as a popular seductive rhetoric, to legitimize western military interventions and the imposition of economic policies in the name of democracy, human rights and free market economy. In this context, it is argued that neoliberalism cannot be analysed without also considering inherent links to imperialism and neo-colonialism, which is being resisted by pan-African movements.
\end{abstract}

\section{INTRODUCTION}

Neoliberalism is the grand political and economic project of our time that since the early 1980s has had a tremendous effect on most people around the world. It penetrates private homes through the dominant media, shapes working environments in form of fierce competition and anti-labour legislation, increases the gap between rich and poor and determines the architectural design of public and private spaces in form of gated communities and increased surveillance systems.

The World Economic Forum at Davos was the locus for promoting the theory, which took form as a policy known as the "Washington Consensus" (Wallerstein 2004). This consensus is a convergence of the policies of the World Bank, the IMF, US Treasury, and subsequently other institutions such as the WTO and the European Central Bank. Neoliberalism cannot be analysed in isolation from the globalisation and imperialism that neoliberalism is a part of a hegemonic project, which concentrates power and wealth in local and trans-national elite groups around the world by transferring state owned assets to private people and Trans-National Corporations (Saad-Filho \& Johnston 2005). 


\section{JOURNAL OF WORLD-SYSTEMS RESEARCH}

For the proponents of the neoliberal project, economic growth and development, through free market economies and free trade, is the way ahead to ensure freedom, democracy and sustainable peace (US National security report 2002). For most critics, neoliberalism is a trans-national elite project, which under the guise of a seductive rhetoric transfers power and wealth from the public sphere to a small elite, by rolling back the welfare state as the redistributive power and privatising public assets. However, outside the academic environment and the business community, the term neoliberalism and the powers behind the project remain obscure and largely unknown (McChesney 1999).

This paper will, from a historical perspective, analyse the neoliberal project in order to understand the ideology and powers behind it. From this perspective it will be argued that the international development agenda, which has dominated the Less Economic Developed Countries (LEDCs) in the past 25 years, has more to do with Western economic and political interests, than with a real intention to reduce poverty and ensure a sustainable development. By drawing on examples from the conflict ridden West African region it will be argued that the long-standing resistance to neo-colonialism automatically becomes a resistance to the neoliberal project, which is currently being imposed in Liberia under the protection of UN peacekeeping forces.

\section{NEOLIBERALISM IN WORLD-HISTORICAL CONTEXT}

The rhetoric behind the neoliberal globalisation presents itself as being modern and progressive. In this rhetoric, the state by definition is inefficient in opposition to the private sector, which per definition is effective and innovative (Saad-Filho 2005). As Bourdieu (2001) notes, neoliberalism becomes a force of attraction because the lines between the technology and speculative economic politics are being blurred. In this way, neoliberalism becomes loaded with a symbolic power because technological progress is being perceived as a result of neoliberalism and therefore a natural force for development, hence many critics of neoliberal globalisation are perceived as against progress and development. However, this perception is both misleading and dangerous. It is misleading because most major technological advances of the twentieth century, such as the transistor, radar, computers, nuclear fission, laser technology and the World Wide Web were created through strong state interventions in capitalist economies and not through free market economies (Chang \& Grabel 2004). It is dangerous because it diverts mainstream attention away from the real ideologies and powers behind the neoliberal project.

In the first instance neoliberalism is in theory, policy and practice, the framework for policy makers in the international agencies such as the World Bank, the IMF, WTO, US Treasury and the European Central Bank. It has, a theoretical and intellectual history reaching back to classical political economists such as Adam Smith. Neoliberalism proposes that human well-being can best be advanced by liberating individual entrepreneurial freedoms and skills within an institutional framework. The role of the state is reduced to protect private property rights through police, military, and legal structures and to guarantee the quality and integrity of money and proper functioning of markets. Socio-economic rights such as education and healthcare are best ensure through the free market, where services are delivered by private providers. If markets do not exist, they must be created by state intervention if necessary.

Arrighi and Jason (2001) note that although the notion of neoliberalism or 'neoliberal globalisation' are presented as a completely new phase of capitalist development to which there are no alternatives, it is only the language, the technology and to some degree the 
concepts that have changed. Examining the writings of classical economists such as Adam Smith, it can be argued that the rhetoric and arguments used today by the proponents of neoliberalism are to a significant degree identical to the writings of the classical economist of the $18^{\text {th }}$ century.

When the former chief economist of the World Bank and Nobel price winner, Joseph Stiglitz, argues that the 1980s IMF's Structural Adjustment Programmes (SAPs) failed, partly because of inappropriate "sequencing" and "pacing" of the economic programs and reforms, he can refer to Adam Smith who in 1776 wrote on deregulation, subsistence and free trade that:

Humanity may in this case require that the freedom of trade should be restored only by slow gradations, and with a good deal of reserve and circumspection... to ensure not to deprive all at once many thousands of our people of their ordinary employment and means of subsistence (Smith 1776: 307).

The 1980s Structural Adjustment Programmes did deprive all at once many millions of people of their ordinary employment and means of subsistence, but this did not change the neoliberal discourse (Milanovic 2003). Neoliberal thinking has become hegemonic and created a 'new normalcy' and 'common sense' among capitalist dominated societies and countries. Failed neoliberal policies are being replaced by other neoliberal policies defended in terms of 'logical' explanations and positive rhetoric such as 'voices of the poor', Poverty Reduction Strategies and 'participatory' frameworks.

It is crucial to distinguish between the 'logical' and positive rhetoric of neoliberalism and the actual practice of neoliberalism. Usually, neoliberalism is presented as a humanitarian project, serving to protect democracy, human rights and freedom of trade, and its dissemination to other nations is framed even as the obligation of the greatest powers on earth, as the way to obtain perpetual peace (US National security report 2002). Harvey (2005) notes that neoliberalism can be interpreted as a "utopian" project to realise a theoretical design for the reorganisation of international capitalism. But in practise neoliberalism has more to do with a political project that aims to re-establish the conditions for capital accumulation and to restore the power of the economic elites. Expecting that the freedom of trade will be entirely implemented was for Adam Smith as:

Absurd as to expect that an Oceana or Utopia should ever be established. Not only the prejudices of the public, but what is much more unconquerable, the private interests of the many individuals, irresistibly oppose it (Smith 1776:309).

From this perspective neoliberalism may be better understood from a global and worldhistorical perspective as a political construction and a hegemonic project that aims to concentrate power and wealth in elite groups around the world. Bourdieu (2001) argues that this project has strong parallels to the medieval feudal system, in an analysis that connects neoliberalism to the struggle for power and wealth between social classes and the balance of power within and between states, markets and civil societies.

It can be argued that the French Revolution in 1789 and the "social revolution" in 1848 were only the beginning of a battle across the Left-Right political spectrum, which is still reflected in today's anti-neoliberal globalisation movements. Where the conservatives and liberals prioritise individual responsibility and the maintenance of inherent or natural 


\section{JOURNAL OF WORLD-SYSTEMS RESEARCH}

inequalities between people, the radical anti-systemic movements prioritise social equality (Wallerstein 2004). In the past two centuries, the radical movements have been key political players. Most states in the West established themselves as "liberal states" in the years up to the First World War, and pressure from the radical movements ensured gradual extension of the suffrage, increased access to education and health care, and protection of citizens against harm in the workplace. These changes are reflected in the legalization of the trade unions under Napoleon III and in Bismarck's invention of the interventionist welfare state (ibid). Realism (real-politics) as the dominant political practice in international relations as well as within nation states, perceives humans as not inherently benevolent, and advancement of socio-economic rights must come through massive pressure from the different interest groups (Morgenthau 1978).

\section{The Bretton Wood System, the US Dollar and the Debt Crisis}

Since realism by definition defines humans as selfish and states as aggressive, peace must be maintained by balancing power between social groups within nations, as well as among nations, which leads to a complexity of relations within states as well as between states (Morgenthau 1978). Social groups and states are forged into a complex relationship of enemies, competitors and alliances, and to reduce conflicts between competing capitalist powers, the gold standard, where currencies were convertible into gold at a fixed rate, was in force from around 1870 to 1914, and subsequently reintroduced in 1925 (Toporowski 2005). This system was in general considered as "an essential factor in the maintenance of a reasonable measure of international stability, for which there is no practicable substitute" (League of Nations 1930 in Toporowski 2005).

At the end of the Second World War, the political leaders of the Western Allies sought to establish a monetary practice at an intergovernmental level at the Bretton Woods conference in the US 1944. This marks the beginning of Keynesian macroeconomics, which advocates control over markets as well as state intervention in the economy, in contrast to liberalism, which advocates non-intervention (Lapavitsas 2005). However, by then it was not possible for most central banks to return to the gold standard, because four-fifths of the gold outside the Soviet Union was in the US (Toporowski 2005), including much of the Nazi gold, such as looted jewellery and gold teeth, which can be traced back to the Holocaust in Nazi Germany (Mazurovski 2005). Instead, the Federal Reserve Bank of New York was given the responsibility of keeping the US dollar convertible for gold at a rate of US\$ 35 per fine ounce of gold. The IMF was set up to monitor the system of fixed exchange rates, which could not be changed by governments without the approval of the IMF. The IMF would lend dollars under strict conditions if a central bank was running out of gold or dollars with which to maintain their fixed exchange rate (Toporowski 2005). The International Bank for Reconstruction and Development (IBRD) was also set up at the Bretton Woods to help finance the reconstruction of countries devastated by the war. Subsequently the IBRD expanded to a group of five institutions known as the World Bank, which became one of the most influential development organisations, tasked with prescribing development policies and financing development programmes in poor countries (World Bank 2006a). The establishment of a trade organisation to provide an international forum to encourage free trade between member states was also discussed at Bretton Woods, but an agreement could not be reached. As a compromise, the General Agreement on Tariffs and Trade (GATT) was established in 1947. After the 1986-94 Uruguay Round, the World Trade Organisation came into being in 1995 (WTO 2006). 
The Keynesian compromise between the end of the Second World War and the start of the 1970s experienced the largest expansion of productive structures and economy in history (Chang \& Grabel 2004). The US dollar was the only currency with which all other currencies and assets could be bought, which put the US in a hegemonic position of the economic system. However, in order to finance the US war in Vietnam, the US printed and spent more money than their gold reserves allowed (Toporowski 2005). A crisis point of this policy was reached in 1970-71 when some foreign central banks tried to convert their dollar reserves into gold. The US government was not able to buy back its dollars in gold, and unilaterally Nixon made the dollar inconvertible to gold, known as the "Nixon Shock". The US dollar became a fiat currency which marks the end of the traditional Bretton Woods (ibid) and in March 1973 the Bretton Woods reopened in a floating currency regime.

The oil crisis in 1973-74 resulted in high unemployment and high inflation, which challenging the 'scientific' economic intervention of the major capitalist states. Increased public expenditure led to persistent government deficits and appeared to exacerbate the phenomena of global crisis, leading to the destruction of Keynesianism (Lapavitsas 2005). The critics of Keynesianism were largely advocates of Friedman's monetarism, and the key economic problem of the 1970s was treated by Friedman as a purely monetary phenomenon resulting from too much money chasing after too few goods. If governments wished to avoid inflation, they had to rely on the ancient Quantity Theory of Money and restrain the growth of the money supply, a policy which was adopted by the Thatcher government in Britain and the Reagan administration in the USA in the 1980s (ibid).

During the period of Keynesianism there was a strong opposition that had also been present in the period of the New Deal. Keynes was a member of the British socialist Fabian Society that was committed to gradual rather than revolutionary social reforms. The Fabian socialism was in direct opposition to both the liberal and the conservative values; hence these groups have naturally played a significant role in the destruction of Keynesianism as a step to launch a liberal revival. However, as Palley (2005) argues, the ultimate cause of the change from Keynesianism to neoliberalism is to be found in the intellectual divisions and in the failure of Keynesianism to develop public understandings of the economy that could compete with the neoliberal rhetoric of 'free markets'. The Cold War in general fostered antipathy to the notion of limitations to market capitalism, and state intervention and collective economic action was associated with the communist approach to economic management. This antipathy provided fertile ground for popularising an economic rhetoric which spoke of 'natural free markets' (ibid).

The Keynesian compromise and stabilisation policies, which attached the US dollar to an indirect gold standard, can be argued also to mark the beginning of the hegemony of the US dollar in international finance that increasingly becomes backed by military power. Powerful institutions, perhaps most notably the World Bank, have some significant links to the military branches of the US. Three years before the collapse of the Bretton Woods Agreement the former US Secretary of Defence Robert McNamara, who held a considerable responsibility for the Vietnam War, and who is considered a war criminal by many commentators (McNamara 2003), was appointed as the fifth President of the World Bank in 1968. The link between the World Bank and US military is further accentuated with the appointment in 2005 of former US Deputy Secretary of Defence Paul Wolfowitz, who is perceived as a prominent architect of the Bush Doctrine and a co-engineer of the illegal US military invasion of Iraq in 2003, known as "Operation Iraqi Freedom" (Watson, 2005).

By connecting the US dollar to the international oil market and backing the currency with military power the US has succeeded in sustaining the hegemony of the US dollar. From 1972 to 1974, the US government negotiated, through the US - Saudi Arabian Joint 


\section{JOURNAL OF WORLD-SYSTEMS RESEARCH}

Economic Commission, that Saudi oil would only be traded in US dollars, thus ensuring a continued demand for the US dollar. In return the US provided technical and military support to the Saudi regime (Gokay 2006). Appreciation of this agreement was in 2002 expressed by a former US ambassador to Saudi Arabia, who told a committee of the US Congress:

...one of the major things that the Saudis have historically done, in part out of friendship with the US, and out of their association with us, is to insist that oil continues to be priced in dollars. Therefore the US Treasury can print money and buy oil, which is an advantage no other country has (Freeman, 2000: in latter part of transcript).

In other words, the US ability to maintain this hegemony relies on dependency of the US dollar system, and the limitations of potential challengers. Saddam Hussein obviously challenged this hegemony in 2000 by insisting that Iraq's oil should be sold for Euros. After Operation Iraqi Freedom, the oil was again traded in US dollar (ibid \& Hoyos \& Morrison 2003)

The early 1970s also mark the first stages of the debt crisis. In reaction to the "October war" in 1973, the Organisation of Petroleum Exporting Countries (OPEC) imposed a sharp rise in oil prices, which brought to those states huge windfall revenues. These revenues were deposited in private Northern banks, which in turn lent the funds to oilconsuming countries in the Third World, thus for a period boosting their economic growth (Radice 2005). In 1979 the US Federal Reserve, under the leadership of Paul Volcker, decided to suddenly increase interest rates, thereby increasing the cost of debt service. This event is often referred to as the "1979 coup", and it marks the beginning of the "Third World Debt Crisis" and the neoliberal project (Duménil \& Lévy 2005).

In August 1982 the government of Mexico announced that it was unable to ensure its earlier payment commitments (ibid), and subsequently more than 30 other countries followed this lead. In response, the IMF programmes aimed at 're-stabilising' and 'adjusting' the macroeconomic fundamentals' of debtor countries in order to secure repayment. These programmes became known as the Structural Adjustment Programmes (SAPs) in the 1980s, today known as Poverty Reduction Strategy Papers (Colás 2005), and represent the core of the neoliberal international development agenda.

\section{THE INTERNATIONAL DEVELOPMENT AGENDA}

Development can be perceived as the choice of institutions that paves the path to the kind of development that is desired. These choices are inextricable from political ideologies and the issue of power projection into weaker states. The two decades after the Second World War may have seen the end of one type of colonial empire. However, many African politicians and intellectuals argue that traditional colonialism was replaced by a new type of imperialism that is perhaps best captured in Nkrumah's notion of neo-colonialism, a notion which became a central part of the theoretical underpinnings of the Organisation of African Unity.

The rivalry between the two superpowers that emerged after the Second World War provided different models of development supported by financial aid, technical assistance, and military support. Modernisation in terms of industrialisation becomes the shared destination in the 1960's and 1970's. Marxists saw this industrialised destination as a Soviet state-socialist future where a universal modernist model is imposed on the so-called 'backward' societies. This approach was legitimised by the fact that the Soviet Union over 
very short time went through a transformation from a feudal society to a relatively advanced industrial society, most notably in the 1930's while the West experienced the Great Depression (Fine \& Saad-Filho 2006). Proponents of US-style modernization saw the capitalist free market and liberal democracy as the destination, but in general the European social democracy in form of the Keynesian Consensus became the be dominant approach, or as Leys (1996) puts it: "The goal of development was growth; the agent of development was the state and the means of development were Keynesian macroeconomic policy instruments" (ibid: 7).

The traditional colonial economies were perceived as extractive and exploitable, in the service of the Western powers. For many independent African states, development was to be achieved through 'nation building' and nationalism with a common sense of identity/citizenship, common language and symbols, national holidays and celebrations, within the borders imposed by the colonial regimes. National development and planning was in the core of developmentalism, and the World Bank was a leading agency in the design and methodologies of national development plans in the 1950s and 1960s. Modernisation was not discussed as being socialist or capitalist, but it was just named as "development" (Leys1996). Although Overseas Development Assistance (ODA) became a central economic tool of the US for advancing its geopolitical interests and preventing the spread of communism (Veltmeyer \& Petras 2005), it can be argued that the mainstream literature on 'development' presents 'development' as a positive project, where the benevolent strong states give financial assistance to weaker states to help them through the transition from 'underdeveloped' societies to modern industrialised societies. While the notion of realism was dominant during the Cold War, considerations of Western covert intelligence operations, assignation of foreign leaders, proxy wars and neo-colonialism have been diluted, if not completely excluded, in most Western mainstream analysis written on development and modernisation theory.

The Underdevelopment Theories, most notable the Dependency Theory and WorldSystem Analysis may provide a more comprehensive picture of 'development' that incorporates Western covert operations and wars by proxy, and that includes the notion of imperialism and neo-colonialism. As influential scholars such as Paul Baran (1957), Andre Gunder Frank (1967) and Wallerstein (1992) argues, economic development in underdeveloped countries is profoundly inimical to the dominant interests in the advanced capitalist countries. To avoid such development strong states will form alliances with domestic elites in the weak states, who will ensure that the strong states will have easy access to natural resources and cheap labour and thus be able to maintain traditional modes of surplus extraction. From this perspective aid is intended to undertake the interests of the core capitalist states and to keep competing capitalist states at bay, by ensuring functional military structures, and the maintenance of law and order through so-called development projects.

Underdevelopment theory and its focus on exploitation of the periphery, as captured in Frank's phrase "the development of under development", could not be ignored in the 1970s. As Leys argues, the 1970s became an era of dependency theory and the international 'development community' could no longer ignore these perspectives. In 1972 the Labour Office called for "redistribution with growth" and the World Bank adopted in the following year the principle of meeting "basic needs". However, it can be argued that the attempt to implement these concessions was 'untimely' and did not have much impact on the opinion in the so-called Third World that perceived the Bretton Woods system as designed to benefit the states that had created it. In 1974, the "Declaration on the Establishment of a New International Economic Order" (NIEO) was adopted by the UN General Assembly. Although the declaration acknowledges the past three decades of technological and economic progress, the declaration addresses an increasing gap between the developed and the developing 


\section{JOURNAL OF WORLD-SYSTEMS RESEARCH}

countries and an unequal distribution of wealth, where 70 percent of the world's population account for only 30 percent of the world's income. The declaration considers the independence from colonial domination to be the greatest and most significant achievement of the 1950's and 1960's, but states that:

the remaining vestiges of alien and colonial domination, foreign occupation, racial discrimination, apartheid and neo-colonialism in all its forms continue to be among the greatest obstacles to the full emancipation and progress of the developing countries and all the peoples involved (UN General Assembly 1974. Resolutions A/Res/s-6/3201 adopted 1 May 1974.).

In opposition to the positive notion of 'development' and the Western mainstream perception of ODA as being altruistic and benevolent, the declaration indicates that economic and military support has more to do with the subordination of the states in the periphery and of their sovereign rights, so that the strong states can ensure a neo-colonial system that will "establish effective control over their natural resources and economic activities that have been or are still under foreign control" (ibid: point 4.i.).

The advancement of the underdevelopment theories, Third World activism and the Non-Aligned nations voting bloc in the UN lobbying in the 1970's for a New Economic International Order declined in 1979 when the US Federal Reserve increased interest rates, marking the beginning of the "Third World Debt Crisis" (Duménil \& Lévy 2005). As Harvey (2005) notes, the World Bank and the IMF changed their already disputed policy framework and made a radical change from Keynesian consensus and state-led development to neoliberalism and free market development.

\section{Human Rights: Liberty versus Equality}

With Regan and Thatcher coming into power, the decline of the welfare state begins and the promotion of neoliberalism accelerates. In the North, the hard-won socio-economic rights begin to decline (Amin 2006) and in the South these rights become even more distant than before (UNHCHR 2002). This development marks a return to liberal capitalism, which had been discredited by the economic, social and political disasters related to the First and Second World War (Radice 2005). Because of the controversial legacy of liberal market economics, it can be argued that the political rhetoric of neoliberalism is crucial to ensure popular support for the implementation of the project. The notion of human rights becomes a catalyst for the promotion of neoliberalism. By presenting neoliberalism as a general defence of human rights, especially the right to freedom, the neoliberal project gains massive popular support from civil society movements and international human rights organisations. However, in the debate on neoliberalism and human rights, the balance between liberty and equality becomes a point of tension between the welfare state system and the neoliberal project.

The decades following the Second World War bring the welfare state system and the ratification of several international conventions supporting human rights (Amin 2006). The Universal Declaration of Human Rights (UDHR) in 1948 can be argued to revitalise the old debate on the balance between "liberty" and "equality". The slogan from the 1789 French Revolution, "Liberty, Equality and Fraternity", is reflected in the first article of the UDHR that states; "all human beings are born free and equal... and should act towards one another in a spirit of brotherhood" (UDHR 1948).

Subsequently, the UN Economic and Social Council was established to promote higher standards of living and to identify solutions to international economic, social and 
health problems, leading to the promotion of the welfare state as a means of redistributing resources more equally (ECOSOC 2006). The Scandinavian countries implemented the most comprehensive form of the welfare state, whereas the US implemented a minimal welfare state. Most other Western countries fell somewhere between these two points (MacGregor 2005). The comprehensive welfare state system build on three main pillars: 1) ensuring individuals and families a minimum income irrespective of the market value of their work, 2) "social contingencies" such as unemployment support and pensions and 3) ensuring all citizens are offered the best standards available in relation to a range of social services such as free health care, free education, free access to information etc. (Briggs 1961). Such a welfare system demands a strong state that is capable of collecting taxes and redistributing resources through social institutions. In this system, the majority of the citizens must possess a particular social capital, based on solidarity with the less privileged people. People must accept a sudden limitation of their individual freedom to ensure a higher level of equality.

This idea of a strong state and high taxation as a guarantor of social-economic policies is opposed by the neoliberal projects, which frame the conflict as a battle between neoliberalism and socialism (MacGregor 2005). As Fukuyama (2006) puts it, "equality cannot be maximised without the intervention of a powerful state that limits individual liberty; liberty cannot be expanded indefinitely without inviting various pernicious forms of social inequality". Fukuyama further argues that each democracy must make tradeoffs between the two, and that this is more a "matter of pragmatic observation and taste than a matter of principle".

However, it can be argued that the balance between liberty and equality goes much deeper than just a matter of "taste" and "pragmatic observation". The balance of liberty and equality is inevitably a matter of balancing power between state, market and civil society, connected to the distribution of resources and a struggle for surplus value between social groups. This is reflected in the Universal Declaration of Human Rights, articles 1 to 21 that represent more the values of "liberty" and articles 22 to 29 that represent more the values of "equality" (UDHR 1948). This dichotomy is further accentuated in the two major international covenants from 1966 that elevate the values expressed in the UDHR to international law in 1976 (OHCHR 2006). The International Covenant of Civil and Political Rights (ICCPR) represents the rights of liberty, which are less costly, and protect property rights. The International Covenant of Economic Social and Cultural Rights (ICESCR) represent equality in the form of socio-economic rights, which are costly and require state interventions to redistribute resources (Evans 2002).

Although the covenants are interdependent, the US, as a prime advocator of neoliberalism, favours as Fukuyama notes, Liberty rights above Equality. This is further accentuated by the fact that US government has not ratified most of the international conventions protecting socio-economic human rights, such as the ICESCR, the Convention on the Rights of the Child, the Convention on the Elimination of All Forms of Discrimination against Women and the International Convention on the Protection of the Rights of All Migrant Workers and Members of Their Families (OHCHR 2006). In spite of this paradox, the neoliberal project has succeeded to present itself as a defender of human rights in general. The state must protect civil and political rights, especially private property rights by sustaining law and order. The expensive social-economic rights must be left to the free market where people will pay for their individual services to private service providers, a model which the World Bank over the past 25 years has named cost recovery, user fees and lately "client power" (WB 2004). 


\section{JOURNAL OF WORLD-SYSTEMS RESEARCH}

\section{The Decline of State-led development and the Rise of Neoliberalism}

The rolling back of the interventionist welfare state system and the transfer of power and wealth from the public to private elites may be considered to be a complicated project in practice, not least because this system has been proven very successful. The decades of stateled development provided the fastest economic growth in modern history from 1960 to 1980 (Chang \& Grabel 2004). In these decades the state protected infant industries and local markets through regulations, subsidies and import/export tariffs, and redistributed resources through taxes. From this perspective, it could be assumed that the neoliberal free market approach to development must have substantial arguments and empirical evidence that can assure even better development and faster growth than the state-led development approach. However, this is not the case and there is no historical evidence that free market economics can provide sound development (Chang 2003).

Without substantial historical evidence, the mantra-like claim of neoliberalism is continually repeated: that the state is inefficient and corrupt and that private corporations are efficient and less corrupt (Saad-Filho 2005). Neoliberal policies range from fiscal austerity, privatisation and liberalisation to decentralisation, deregulation and anti-labour legislation, and are naturalised through the mantra of globalisation as "the only game in town", known as the "Washington Consensus" (Colás 2005,). The 1980's generation of Structural Adjustment Programmes (SAPs), imposed by the IMF as a response to the debt crisis, falls under this Consensus (Stiglitz 2002). As Stiglitz argues, when one perceives the IMF as an institution pursuing policies that are in the interests of creditors, other IMF policies become more understandable. The SAPs have forced weaker states to open their frontiers by lifting import and export restrictions, to remove price controls and state subsidies, to enforce rapid privatisation or divestiture of all or part of state-owned enterprises, to implement user fees for basic services such as education and health and to cut social expenditures (ibid).

The US focused on the SAPs as a tool that could force countries to open their oil sector to foreign companies. From 1982 to 1984 the World Bank funded more than fifty-five oil and gas projects (Juhasz 2006). The World Bank's principal counsel for energy and mining, William Onorato, has stated that the Bank was financing oil projects and writing legal reforms for recipient governments with the specific purpose of increasing the presence of foreign companies (ibid). The conditionality on privatisation and liberalisation imposed by the World Bank has benefited a range of TNCs, such as the water giants, Vivendi and Sues, which now operate in more than 130 countries and control more than 70 percent of the total water industry (Barlow and Clarke 2002).

Although some particular social groups have benefited from the SAPs, the bulk of the populations in the South have experienced the SAPs as a disaster. Latin American countries that followed the SAPs virtually stopped growing, while sub-Saharan Africa has experienced negative growth, and many former Communist economies have simply collapsed (Chang and Grabel 2004). The neoliberal free market approach in the 1980s demonstrated a significant failure (ibid).

\section{From Washington Consensus to Post-Washington Consensus}

While the neoliberals acknowledge that the transition from state-led development to free market approach induces short-term 'adjustment costs', opponents to neoliberalism consider the 1980s as "the lost decade", which has left most of the world's population worse off than before (Elliott 2003). The failure of the SAPs was even recognised by the World Bank in the early 1990s and a new development strategy had to emerge (Milanovic 2003). The World 
Bank also recognised that those countries that did experience significant economic growth in the 1980s, such as China, Taiwan and India, used strong state interventions and protectionism, policies directly opposed to those of the Washington Consensus (World Bank 1993). However, the Bank claims that those which did follow the Washington Consensus and which experienced failure of the SAPs, failed because national governments were not fully committed to implementing the SAPs. So what is needed is more neoliberalism and deeper interventions, presented as a progressive development approach concerned with local participation and needs (Cammack 2004).

With the arrival of Wolfensohn as the new president of the World Bank in 1995 and Clinton's former economic advisor, Stiglitz, in 1997, the 'new' development agenda was engineered. Many commentators present Stiglitz as a hero of the anti-neoliberal globalisation who has declared "war on the entire Washington financial and economics establishment" (Frazer 2002) and a "worthy successor to Keynes", who can "restore the IMF and World Bank to their original purposes" (Blackburn 2002). However, Stiglitz promotes the same neoliberal free market approach as the Washington Consensus but emphasises "extreme care in sequencing - the order of which reforms occur - and pacing" for successful economic programs (Stiglitz 2002: 18). In contrast to the Washington Consensus, which mainly dealt with higher level polices, this 'new' approach entails a comprehensive and complete change at all levels of society, addressing issues from civil society and social capital to good governance and macro-economic policies. This new approach is named the "Post-Washington Consensus" (Stiglitz 1998.).

The Post-Washington consensus is materialised through the World Bank's Comprehensive Development Frameworks (CDF), which deal with everything from aid delivery in complex political emergencies to Poverty Reduction Strategy Papers (PRSPs). The PRSPs are attached to the Enhanced Heavily Indebted Poor Countries Initiative II (HIPC) and represent the central approach to reach the eight millennium goals before 2015. A country's willingness to implement the neoliberal PRSPs becomes an a priori condition for debt relief and international financial assistance (World Bank 2006-b).

Some commentators argue that the PRSPs are old wine in new bottles because the conditions for obtaining loans from the IFIs are still the same today as prescribed during the SAPs (Johnston 2005). However, it may be more profitable to perceive the PRSPs as an even deeper intervention into sovereign states that may be difficult to separate from imperialism and neo-colonialism. Some of the core principles of the PRSPs are that they are 'Comprehensive', that they integrate macroeconomic, structural, sectoral and social elements, and that there is a 'Long Term' focus on reforming institutions and capacity building as well as short-terms goals. The PRSPs are 'Country-driven', which means that the government writes and owns the PRSPs, which must be 'Result-oriented' with targets for poverty reduction that are tangible and monitorable. The 'Participatory' element involves all relevant stakeholders in formulation and implementation based on 'Partnership' between government and other actors such as INGOs, civil society, international institutions and other agencies (World Bank 2006-b).

In spite of the positive wording and rhetoric in relation to the PRSPs, local ownership can be perceived as an approach to embed the local elite into the neoliberal administrative structures to exploit the local formal and informal structures. As Robinson (2004) argues, neoliberal globalisation increasingly institutionalises a powerful transnational capitalist class which characterises the state and the political apparatus. Perceiving the transition from the Washington Consensus to the Post-Washington Consensus as a logical continuation of an imperial project where IMF's "shock therapy" and anti-state SAPs demolished the existing structures for then to rebuild "new institutions" in the image of the market, may be more 


\section{JOURNAL OF WORLD-SYSTEMS RESEARCH}

beneficial than perceiving the Post-Washington Consensus and the PRSPs as completely new approaches to development. As UNCTAD (2002) formulates it; "the first generation of reforms was to get "prices right" and the second generation of reforms is to get "institutions right".

\section{New Institutions and Democracy}

Getting "institutions right" can be argued to be crucial for the neoliberal project, because institutions set the "rule of the game" and offer services, choices, incentives and constraints to internal as well as external actors (Khan 2002: 2). Reforms of institutions are deeply political, and the power allocated will necessarily reflect the vision of what kind of development is desired (ibid), hence it must be questioned "who" decides what institutions are desirable and how much power should be allocated. Although the Post-Washington Consensus advocates democracy where 'the people' can decide, democracy is clearly restricted to certain sorts of democratically elected governments that will comply with the neoliberal project (Harvey 2003). When neoliberals advocate democracy they mean "liberal democracy", which supports the liberty rights and protects private property as outlined in the ICCPR. "Social democracy", which supports the more expensive socio-economic rights as outlined in the ICESCR and demands strong state intervention to redistribute resources through taxation, is not desired (Evans 2001).

From this perspective it can be argued that the Post-Washington Consensus seeks particular types of institution that will underpin the neoliberal project. In this context the "New Institutions" (NI) become a core element of the 'good governance' agenda and the PRSPs. As Wallerstein (2004) points out, TNCs are strongly dependent on strong states to protect their assets and economic interests. States set the conditions under which goods, capital and persons can cross their boundaries, and lay down the rules and regulation for operation. In pursuit of short term profits, TNCs prefer to operate in states that provide the necessary infrastructure, a strong legal and enforcement system (law, police and army) to ensure property rights, flexible labour regulations, low taxation, and possibilities for externalisation of cost. The latter often has a negative impact in the form of environment degradation, such as deforestation and pollution. Equally, TNCs prefer to be based in strong states that have the political and diplomatic power to influence the governments of the weaker state to provide optimal conditions for the operations of the TNCs (ibid).

The traditional distinctions between state and market, around which liberal democratic institutions were constructed, have become blurred, and the real political power lies in the corporate economy, the mass media and the IFIs (Kaldor 1999). Through privatisation schemes, the control of state-owned enterprises (SOEs) assets is being transferred to private elites who have secured increased veto power over the legislative and policy domain. Liberalisation and deregulation of markets provide large investors and firms with the additional power that they can merely threaten to relocate as a potent means of blocking government and citizen initiatives that may oppose the interests of the TNC (MacEwan 2005).

From this perspective it can be argued that the current rhetoric of democracy has more to do with legitimising the neoliberal project, which actually undermines democracy, development, and national autonomy. As Chang (2003) points out, the neoliberal international development policies are in direct opposition to the policies used by the successful developers in the past centuries. Successful industrial countries have protected their infant industries through regulation on import of competitive goods and provided state subsidies until they can compete on the international market. Insisting that weaker states adopt policies that are 
opposite to those, which according to historical evidence lead to industrial development, does not make sense at all. The only explanation, as Chang (2003) argues, is that the strong states are deliberately 'kicking away the ladder' or as List (ibid) puts it:

it is a very common clever device that when anyone has attained the summit of greatness, he kicks away the ladder by which he has climbed up, in order to deprive others the means of climbing up after him (List 1841, in Chang 2004:4).

Although notion of "ladder kicking" is controversial in the West, most states that are exposed to the imposition of neoliberal policies, consider the issue of "ladder kicking" to be a fact on the ground (confidential source A 2006). This provides a dilemma for many governments and populations because more than two decades of neoliberalism have proved its failure to deliver development for the poor (Milanovic 2003). In 2000, the debt of the countries in the South was four times larger than in 1980 (Duménil \& Lévy 2005). The number of undernourished people worldwide has risen to more than 852 million (WFP 2005). More than 2.8 billion people live for less than $2 \$$ per day, and in Sub-Saharan Africa half of the population is poorer now than in 1990, with 46 per cent of the population living on less than $1 \$$ per day (UNDP 2002). More than 1 billion people do not have access to clean water and 2.6 billion people do not have adequate sanitation (UNDP 2006a). Every year, more than 13 million children below five years die because of lack of access to basic needs (UNICEF 2005).

As previously mentioned, state-led development with focus on equality and socioeconomic rights has in the past proven successful. However, such approaches are in opposition to the neoliberal ideology, and a country's 'choice' of institutions will be assessed by the World Bank's Country Policy Institutional Assessment (CPIA) (World Bank 2005). The less a country complies with the neoliberal free market policies, the lower the country will rank on the World Bank's CPIA. In 2004 around 50 countries ranked so low on the CPIA that they were classified as Low Income Countries Under Stress (LICUS). Many of these countries will have difficulty getting access to international financial loans, since they are not considered to be "good governments" (World Bank 2006c). In the LICUS, which are often characterised by civil unrest and armed conflicts, the World Bank will often bypass the government and deliver assistance to the civil society by setting up an Independent Service Authority, from where private firms, INGO, civil society organisations, Private Military Corporations, etc. can compete for contracts (ibid) to implement 'humanitarian' assignments, in what can be considered as a conversion of the humanitarian space to a humanitarian market place (Feinstein 2005).

\section{NEOLIBERAL IMPERIALISM AND RESISTANCE IN PRACTICE}

Because of the severe human consequences of the neoliberal project, it can be argued that many governments and social movements will automatically oppose neoliberalism. In this way neoliberalism may provide an impetus for violent conflicts, wars and global instability, leading to calls for increased security measures and military interventions, which must be legitimized. Arendt (1969) argues that violence and power are opposites. Violence appears where power is in jeopardy, however, violence needs legitimacy through the goal it pursues. It will be argued that legitimisation of neoliberal military interventions is sought through the dominant media and the mainstream literature by presenting such interventions as a force of 


\section{JOURNAL OF WORLD-SYSTEMS RESEARCH}

good where democracy, human rights, and free market economic will lead to a perpetual peace. As Bourdieu (1991) notes, rhetoric, words and slogans, creates and maintains the social order by imposing visions and division to actualise and transform symbolic power into legitimated official politics. On the political scene, the words "democracy" and "democratisation" are used as political symbols of 'good' to legitimise official neoliberal politics in line with human rights. But as with human rights, the meaning behind the rhetoric of democracy, and the power of this rhetoric that is projected through the dominant media and mainstream literature, is rarely critically questioned.

Democracy has become a common popular word with little distinction between the different forms of democracy, such as social democracy, liberal democracy, direct democracy, etc. and in the context of neoliberal hegemony there may be a further a danger of not distinguishing between democracies and plutocracies. A number of pro-democratic social movements and think tanks can be argued to publicly advocate social democracy and socioeconomic rights, while in real terms supporting the neoliberal project. The UK New Labour party and the revitalized Fabian Society is perhaps an eminent example on how the lines between different types of democracies is being blurred. Inspired by Giddens's (1998) "Third Way" as an overarching label to renew social democracy in the age of globalisation, a significant step has been taken towards the neoliberal project. Under the leadership of New Labour in the UK, the Schröder-led Social Democratic government in Germany and the 'new Democratic' project of Clinton in the US, liberalisation and privatisation has taken place with little resistance, often described as 'neoliberalism with a human face' (Arestis \& Sawyer 2005). Archibugi (2004) notes that with the collapse of the soviet system many people believed that the gates to democracy, as the dominant system of global governance, had opened and a movement of cosmopolitan democracy urged Western states to progressively apply their principles of democracy in form of the rule of law and shared participation as a "New World Order". Although Archibugi argues that leading Western liberal states have not responded to the appeals of the cosmopolitan democracy, the proponents of cosmopolitan democracy can be argued to have become closely associated with the proponents of the liberal democratic peace theory.

Most proponents of cosmopolitan democracy that distance themselves from realism, such as Falk and Archibugi, arguably face a number of paradoxes when suppressing this grim theory for the noble course of cosmopolitan democracy. On the one hand they are very critical on US hegemony, violation of international law and projection of military power into foreign states, but on the other hand they seem to accept a number of military interventions, legitimised by the noble cause of promoting human rights and democracy. Falk (2003) consider the illegal war in Kosovo as a necessary war from a humanitarian perspective, which therefore becomes a moral war that triumphs international law. Falk also agrees with the US war in Afghanistan as a proper strategy of self-defence. In both cases it can be argued that Falk, in spite of his strong criticism of US use of military force, accepts the use of military force in violation of international law in certain cases, and advocates for broader peacekeeping and humanitarian functions to be adopted by the UN. Similarly ambiguous statements comes from Archibugi, who is critical to the US and UK intervention in Iraq, which violated international law, but on the other hand he argues that the international community lacked non-coercive instruments to stop the violation of human rights by the Iraqi government, while suggesting that smart sanctions would have been more appropriate.

Many movements that promote various forms of democracy and human rights may be driven by ideological and noble intensions to reject the defence of national sovereignty as a counter-balance to America's hegemony. Instead they proactively promote global governance as a mean to counter US hegemony and often advocate for military interventions in the name 
of democracy and human rights to protect people who are subjected to oppression from their own governments. However, from a realist perspective, such system of global governance may be considered as a utopia, and the promotion of reforms to existing global institutions and the establishment of additional global institutions may further sustain and enforce the hegemony of the US and its allies. As Chandler (2000) notes, many international organisations, such as the IMF the WB, WTO and NATO serve the purpose of maintaining and preserving the interests of US hegemony. The empowerment of global institutions will lead to a decrease in the independence of the weaker states and ultimately reinforce the current hegemonic power. The period of UN reform and democratisation of global governance has witnessed a significant increase of Western military interventions based on the rhetoric of global order, human rights and democracy. By ignoring the underlying political and economic interests, movements that promote democracy and human rights may further underpin a mix of 'just' war theory and a revitalisation of Kipling's "white man's burden", in a modern form where the promotion of 'democracy' and 'human rights' becomes the new gospel that underpins the liberal democratic peace theory, that is based on Kant's essay (1795) "Project for a Perpetual Peace".

The revitalisation of democratic peace theory at the end of the Cold War can be argued to unite a number of different political camps in spite of different lineages and normative thrusts. By welcoming Fukuyama's (1989) "End of History" and indirectly declare realism for dead by stating that "the end of history... is the end point of mankind's ideological evolution and the universalisation of Western liberal democracy as the final form of human government" (ibid) the neoliberals and the neoconservatives begin to converge towards a common interest in promoting the liberal democratic peace theory, arguable with the support of constructivism. The notion of democratic peace is arguably a new convenient tool to legitimise US hegemony and projection of military power into strategic areas around the world. Powerful politicians, such as Bill Clinton and George Bush, repeatedly advocate democracy, human rights and free market economics as the way to ensure a peaceful world because 'democracies do not go to war with each other' (Bush 2004; Clinton 1994). This popular mainstream political mantra is underpinned by influential academics such as Doyle, who has re-examined the 'peaceful' behaviour of liberal democratic states (Waltz, 2000), and Rummel's empirical research that is based on strongly contested data. Mann (1999) notes that Rummel's statistic outcomes are weak and strongly questionable and states that Rummel do not consider the more important cases of 'democratic' mass killings, like the fire-bombing of Dresden and Tokyo, the dropping of the atomic bombs or the napalming of the Vietnamese countryside, the Pakistan and India conflict. Mann's definition of democracies may be questioned, and perhaps better examples can be drawn from a number of cover military operations carried out by states defined as 'democratic', which in general is ignored in the mainstream debate. Chile in the early 1970s provides one example out of many where democratic forces have clashed with US interests. Parenti (1995) notes that former US Secretary of State Henry Kissinger favoured capitalist economy above democracy (ibid: 76) and considered the election in Chile as too important to be left to the Chilean voters, as reflected in Kissinger's statement; "I don't see why we need to stand by and watch a country go communist due to the irresponsibility of its people" (ibid: 143). Subsequently the US supported a military coup against Chile's President Allende and installed a military regime lead by Augusto Pinochet (ibid).

Chomsky (2002) notes that Woodrow Wilson declared war on "Prussian dictatorship" during the First World War, when in fact at that time Prussia had a democratically elected parliament. This marks the beginning of a new era of propaganda, where control of the dominant media and information becomes for democracies what violence is for authoritarian 


\section{JOURNAL OF WORLD-SYSTEMS RESEARCH}

regimes (ibid). Woodrow Wilson and Alexander Hamilton invested prodigiously in war propaganda that imprinted "democracy" in the American geopolitical lexicon as the highest term of praise (Schwartz \& Skinner 1999).

\section{The Rhetoric of Empires and Civil Society}

The chaos caused by neoliberalism is mobilising social movements, from conservative Islamist networks to the revolutionary left, to oppose neoliberal imperialism and US hegemony (Sinha 2005). In some instances these movements poses real threats to US political and economic interests, and the groups are therefore being classified as anti-American, antiglobalisation movements, terrorists, rogue states or similar. This opposition to US hegemony must be controlled by changing legislations and additional legislation such as the US PATRIOT act of 2001, new surveillance systems, increased police forces and military interventions. Since these movements are a threat to the interests of both the neoliberalists and the neo-conservatives, these two camps naturally converge to a certain extent, based on common interests. Such convergence can be argued to have clear parallels to the complexity of relations between the liberals and the conservatives in the wake of the "world revolution" in 1848, where, as Wallerstein (2004) notes; the radicals posed a real threat to the ruling elite.

To reduce the threats from radical movements and to control what Hamilton called the "great beast", the notion of liberal democratic peace may become the most powerful tool to legitimise military interventions as a force for good. Similarly the notion makes it an obligation of the international community to fight 'terrorism' and help implement democracy, human rights and free market economy, as the only way to ensure future peace and economic prosperity. This notion has repeatedly been promoted by the US administration, by both the Republicans and the Democrats, under the umbrella that democracies do not go to war with each other (Bush 2004; Clinton 1994). This discourse is further articulated by The Project for the New American Century (1997) that advocates significant increases in defence spending, to carry out the US global responsibilities such as preserving and extending international order, ensuring political and economic freedom abroad and challenging regimes hostile to US interests and values. Among the signatories to this discourse are significant politicians such Paul Wolfowitz, who subsequently became the president of the World Bank, Dick Cheney, Donald Rumsfeld and influential academics such as Fukuyama.

The introduction of liberal democratic peace theory necessarily displaces realism/power politics, which has been the dominant theory in international relations for centuries. But as Waltz (2000) argues, if the system on which a theory is based changes, the theory will no longer apply. The end of the Cold War was not a change "of" the world system but a change "in" the world system and therefore the democratic peace theory remains as a thesis while realism is still the dominant theory on which international politics must be analysed. However, realism does paint a rather pessimistic and grim picture of the development agenda and world politics, emphasising self-interest, international greed and competition for access to resources, with frequent application of military force (Mearsheimer 1995). The positive rhetoric of liberal democratic peace, may be a more seductive and convenient way of overruling state sovereignty and legitimising military interventions as a force for good, and for justifying imposition of the neoliberal project in the name of freedom, democracy, human rights and free market economy, while the interventions are in reality primarily driven by political and economic interests rather than humanitarian concerns.

At this point, the arguments of the realists correspond well to World-System Analysis, in spite of different perceptions and understandings of the world system. As Wallerstein (2004) argues, strong states relate to weak states by pressuring them to install and 
keep in power persons whom will ensure the interests of the strong states and further placing pressures on other weak states to get them to conform to the policy needs of the strong state. Gowan (2004) points out that the modern empire states prefer not to use traditional command power but indirect or co-optive power behaviour, i.e. getting others to want what you want" (Nye 1990 in Gowan 2004: 488). This may firstly be a technique to get other strong states to want what the US wants, by shaping the political environment in such a way that other states become dependent on military protection from the US or in form of economic dependency. However, it is arguably also an important tool for creating popular support in civil society by manufacturing consent through the dominant media and mainstream literature, in order to tame the "great beast" and get large segments of the civil societies to want that the empire state wants.

Whereas in the past, political artists such as musicians and film actors could mobilise civil societies to demonstrate "against" Western military and economic dominance, popular musicians now go on stage to reproduce the positive rhetoric of democracy and human rights as advocates "for" western neoliberal economic and military interventions. In this context, powerful and dominating so-called International Non-Governmental Organisations (INGOs) that are mainly funded by Western institutions (Macrae 1996) play an increasingly important role in "getting the populations to want what the empire state and its allied wants. With perhaps good intentions, powerful INGOs increasingly call upon the US and its allies to take military action under the umbrella of the "Responsibility to Protect" and in the name of democracy and human rights as promoted by the International Commission on Interventions and State Sovereignty (ICISS 2001).

In the early 1990s a number of influential INGOs and aid agencies called for a military intervention in Somalia, to help improve the humanitarian situation on ground. The intervention became a joint US/UN "humanitarian military intervention" under the name "Operation Restore Hope". Most commentators refrained from mentioning that the US willingness to intervene militarily in Somalia could have more to do with oil interests in Somalia than with human protection (Fineman 1993). Nearly two-thirds of Somalia was allocated to US based oil companies, most notable Conoco, Amoco, Chevron and Phillips (ibid). Documents from the US embassy in Mogadishu states that:

Conoco is investing in oil exploration in Somalia on a scale unmatched by its rivals, building roads and airstrips... they have recruited a well armed force of over 100 police to provide security... an oil strike in Somalia would have little or no value unless the country achieves internal peace (Cable from US Embassy in Mogadishu to State Department 1990).

The US State Department and military officials acknowledged that US based oil companies have been very active in Somalia and with the deployment of the US marines, Conoco's compound in Mogadishu was transformed into a de facto American embassy and military headquarter (Fineman 1993).

During the 1990s the relationship between the most influential INGOs and Western military coalitions was further confirmed during "Operation enduring Freedom in Afghanistan in 2001, when US Secretary of State, Colin Powell, confirmed the close relationship between the military coalition and the INGOs by stating:

we have the best relationship with the NGOs who are such a force multiplier for us, such an important part of our combat team, all committed to the same, singular purpose to help humankind (Powell 2001).

Arguable, the crisis in Darfur can be considered as an example of how imposition of visions and divisions are manufactured through control of the dominant media where rhetoric, 


\section{JOURNAL OF WORLD-SYSTEMS RESEARCH}

words and slogan create a popular consent among western civil societies, to push the US administration to do what the administration really wants, namely a military intervention in Darfur, 'to save the people of Darfur' (Bush 2007). As Mamdani (2007) notice, by simplifying and depicting the conflict as "Arabs against Africans" and promoting a politics of naming genocide, the US administration has succeeded in depoliticising the conflict in Darfur and in unifying a coalition of more than 500 faith-based, humanitarian and human rights organisations in a coalition that would not last if the issue shifted to Iraq. In spite of the fact that the commission of inquiry on Darfur, established by the UN Security Council, concluded that there is no pursuit of genocide in Darfur, coalitions of civil society organisations, such as the Save Darfur (2007) coalition, reproduce the notion of genocide and are pushing for a military intervention.

The International Crisis Group (ICG), that presents itself as a NGO, has produced a number of publications in favour of a military intervention in Darfur (ICG 2007). In spite of the strong political discourse set out by the ICG, these publications are very popular among many INGOs and aid agencies. Although the ICG is funded by Western governments and consist of a board of former politicians, such as the former foreign minister of Australia, a former US ambassador to the UN, Israel, Russia and a former Governor of Hong Kong/former European Commissioner for External Relations (ibid), the publications from the ICG are often referred to as a reliable source of information and objective analysis (UNOCHA 2007). This can be argued to enhance a mainstream consensus among the INGOs and aid agencies operating in Darfur, which further helps the dominant media to maintain the simplified and depoliticised picture of the conflict as one that can be solved by a Western led military intervention. The issue of oil interests in Darfur and the notion of competing powers for access to natural resources have been effectively marginalised in the debate, despite a World Bank-coordinated study in 1991, puts Somalia and Sudan at the top of the list of prospective commercial oil producers among eight East African countries (Fineman 1993). In particular, the oil factor makes many Darfurians to believe that the conflict is partly a result of fierce competition, for access to the Darfurian oil resources, between powerful countries, such as US, UK, France, Russia and China. By extending the Chad-Cameron oil pipeline, the US can extract the Darfurian oil resources if they succeed to get control over the resources in one way or another (confidential sources B 2007). Many politicians and intellectuals in Darfur argue that the US has not been very successful in supporting the rebels; hence the US is now pursuing its interest in Sudan through its dominant position in the UN. Many people in Sudan perceives the UN and the US as being the same, and any military intervention dominated by the US or the UN will therefore, by many Sudanese people, be perceived as a form of US imperialism and neo-colonialism. The Darfurian crisis may therefore deteriorate if any military intervention is perceived as being dominated by the US, either directly or by proxy. Having African soldiers on the ground in Darfur may increase the legitimacy of a military intervention, but this legitimacy will be very limited if the leading commanders and decision makers are from Western countries, or from other African countries that are considered to be 'friendly' towards US interests in general. In such case, the military intervention in Darfur may create a similar chaos, to that created by the US-led military intervention in Iraq. Many Sudanese politicians and intellectuals further compare the rhetoric of genocide in Darfur with the rhetoric of weapons of mass destruction in Iraq, in order to raise popular support in the

West. In this context most Western INGOs and aid agencies calling for a military intervention, in the name of human protection, are being perceived as "Trojan horses" of the governments that fund them as a part of an imperial discourse (confidential source C 2007). 


\section{New Imperialism?}

Despite the practice of most influential mainstream commentators, who promote the rhetoric of democratic peace in the West and ignore the critical voices that underpin a realist picture of armed conflicts, it has become more common to perceive the US as a New Empire. As Wood (1999) states, the US intervention in Kosovo, in conjunction with NATO and other allied states, is a new imperialism exerted by the US, in violation of international law. Mann (2003) defines the US illegal intervention in Iraq in 2003 as a "new imperial" and "new militarist" discourse that seems to have arisen.

However, much indicates that the US has been an imperial power for a much longer period, in spite of the fact that the "new imperial" discourse is often dated to either the post9/11 era or the end of the Cold War (Stokes 2005). Confining the analysis of US imperialism to illegal exercise of direct US military power over weaker states in the post-Cold War era, or to post 9/11, may direct focus away from the historical facts that may be crucial for an appropriate analysis of contemporary policies related to the neoliberal project. The past 50 years of history shows that weaker states opposing US political and economic interest are likely to be exposed to armed conflicts, either through proxy wars or by direct US military involvement. The US has militarily attacked more than 70 foreign sovereign states since 1945 (Pilger 2002). Besides this the US has overthrown several democratically elected presidents, such as Iranian Prime Minister Mossadegh in 1953, Chilli's President Allende in 1973 (Chomsky 2000), supported the coup of President Nkrumah in Ghana 1966 (US State Department 2006; Stockwell 1992 ) and ordered the physical removal of Lumumba in Congo (CIA 1999).

The proponents of US imperialism may justify these actions as a force of "good" against "evil", and argue that if the world is going to remain a stable entity, the US as an empire must accept the responsibility that goes with it and intervene to ensure freedom and democracy (Cox 2003). However, this perspective does provide a paradox in that the US and its allies have supported dictatorial regimes such as Mobutu in Congo, Suharto in Indonesia, Saddam Hussein in Iraq (Chomsky 2000), the Mujahidin and the Taliban in Afghanistan (Rashid 2001). The "United States Senate Select Committee to Study Governmental Operations with Respect to Intelligence Activities" (Church Committee), revealed that the socalled "secret wars" of the CIA up to 1975 included more than 900 major operations and 3000 minor operations, which are estimated to have killed more than 6 million civilian people in the Third World from 1945 to 1975 (Church Committee 1975). Many of these operations lead to long armed conflicts or so-called 'civil wars', and since 1975 the CIA budget and number of operations has not decreased, but increased significantly (Stockwell 1991).

In spite of the fact that these activities are illegal according to international law, international sanctions against the US have been proven difficult to apply in reality. Because proponents of US imperialism consider the US to be both distinctive and superior to other nations, the US can go against international law when they have to and enjoy "exceptionalism" (Cox 2003). The International Court of Justice convicted the US for unlawful use of force against Nicaragua in 1986 (ICJ 1986). Subsequently the US simply increased its military and paramilitary activities in Nicaragua and vetoed a draft resolution in the UNSC, which requested all countries to comply with international law (UNCS 1990).

Analysing neoliberalism and the international development agenda from the perspective of democratic peace theory and 'new' imperialism obviously generates a number of paradoxes as outlined above. However, from the perspective of realism the US can be considered as an imperial power that has dominated the international development agenda over the past five decades. Desai (2004) argues that the East Asian financial crisis and the 


\section{JOURNAL OF WORLD-SYSTEMS RESEARCH}

launching of the war on terror can be seen as a passage from one strategy of US imperialism to another, where the US is now more openly in direct control of productive assets and territory, such as in Iraq, as geopolitics and control of oil resources play a new crucial role for the US led international order. However, in most cases the US seems to prefer a strategy of indirect control of national governments, often known as "puppet governments" (Said 1999). Such governments may consist of a national elite, which preserves a relative autonomy and security guarantees, and which plays a role in collective policymaking coordinated by the US (Desai 2004).

\section{Neo-colonialism and Pan-African Resistance}

Although the US may be the most dominant Empire today it can be argued that it is far from the only strong state that practices imperialism, which in most African countries cannot be separated from neo-colonialism. Despite the fact that a form of imperialism is exercised over the entire African continent (Wallerstein 2003), Americans in general, and most mainstream academics in particular, appear uncomfortable with the idea of imperialism (Mabee 2004). However, if one ignores the notions of imperialism and neo-colonialism, it can be argued that one is contributing to a dichotomy of mainstream perception between the West and the South. In the West, populations may perceive imperialism and colonialism as belonging to the past, and the international development agenda as philanthropic and a force of good. In the South populations consider neo-colonisation to be fact on the ground and the international development agenda to be an imperial project to control populations and resources. This dichotomy is visible in the UN Open-ended Working Group (2004). The Security Council, dominated by the Permanent Five (P5), which all are former colonial masters with strong competing political and economic interest around the world, is by many UN members states being accused of being "anachronistic, discriminatory and undemocratic". The P5's use of the formal and "informal" veto power represents a complete erosion of the principles of transparency and accountability of the Security Council (ibid), including the arguments presented by the proponent of a global democratic world order. As the deputy to the UN Secretary General states, there is an understandable hostility by the wider members of the UN towards the Permanent Five who tend more to prioritise their own interests over human rights. Currently there is a perception that anything the US supports must have a secret agenda (Brown 2006).

The events in Somalia and Rwanda in the early 1990s may serve as an illustration of the UN Deputy Secretary General's statement. Somalia was left in a more disastrous situation than before the intervention, after the US military attacked and killed 50 clan leaders during a peace negotiation meeting in July 1993. This operation disturbed the local power balance and increased the local hostility towards the international operation. Three months later an armed clash between groups of Somalis and the US military took place in Mogadishu, and subsequently the UN 'peacekeeping' mission withdrew completely from Somalia (UNOCHA 2006). A decade later, details were exposed of the covert support from the US for particular groups of warlords who fought against undesired groups (Gedi 2006) and in early 2007 the US carried out new bombardments in Somalia to 'fight terrorism' (Pentagon 2007). In Rwanda 1994, more than 800,000 people were killed in a genocide, while the UN decided to withdraw its forces (Dallaire 2003). The passivity of the UN can be directly linked to the UNSC and French/US use of hidden veto (Nahory 2004).

In the dominant media and in mainstream literature many African conflicts are framed as being part of a pre-modern world where barbarians, chaos and disorder prevail, posing a grave threat to Western civilisation and providing bases for terrorism (Cooper 2002). 
Building on contested empirical data from Collier and Hoeffler (2002), the World Bank states that most armed conflicts are driven more by greed than grievance (World Bank 2003). Interestingly, the World Bank only focuses on local greed and not on international greed, in spite of clear evidence of significant Western political, economic and military involvement in most African armed conflicts.

The depiction of African conflicts as being rooted in local barbarianism, greed, ethnicity and religion are being promoted by influential scholars such as Kaplan (1994) and Huntington (1993) and may in the West, depoliticise the conflicts and displace the notions of imperialism, neo-colonialism and proxy wars. However, in Africa the perception of the same events seems to be very different. In Ivory Coast the 'civil war' is by pan-Africanists considered to be French and neo-colonial (Nanga 2005). In 2003 the Government of Ivory Coast started to take control of the water, electricity, telecoms, marine and air transport, and established closer ties to China. This threatened French interests and ownership, and France deployed military troops in Abidjan in 2003. French control of the economic capital was resisted by pan-African pro-government movements who took the streets in anti-French demonstrations (ibid). Ivorian intellectuals and politicians accuse the UN peacekeepers under French command of de facto partition of the country (Koulibaly, 2006). The president of the Ivorian National Assembly has stated that the rebels in the north are puppets paid by France to destabilise the country and orchestrate the plunder by French multinational companies of national resources. Similar accusations of neo-colonialism were expressed in relation to the bilateral deployment of British troops and provision of technical assistants and advisers in most civil ministries in Sierra Leone, 2000. Several influential West African politicians and commentators considered this intervention as a fact that Britain is back in Sierra Leone (Richardson 2006).

As the competition between powerful states may increase in the scramble for the oil resources of West Africa, which according to the Cheney Report is the third most important oil strategic area in the world (NEP 2001), the resistance against neo-colonialism under the umbrella of "pan-Africanism" may increase as well. Many pan-African movements are inspired by people such as Frantz Fanon who advocated socialism as the foundation on which to build an African identity, and justified violence as a mean to achieve independence through statements such as; "colonialism is naked violence and only gives in when confronted with greater violence" (Fanon 1961: 23).

Ghana's first president, Nkrumah (1965), who was overthrown in a coup in 1966, endorsed by the US (US State Dep. 2006), stated that neo-colonialism is the worst form of imperialism, because those who exercise it have little or no responsibility. In extreme cases the imperial powers will intervene directly with their own military, but most commonly neocolonialism is exercised through economic and monetary means, establishing control over foreign exchange through the imposition of a banking system controlled by the imperial power (Nkrumah 1965). For Nkrumah, African Unity was considered to be the first requisite for destroying neo-colonialism (Nkrumah 1973), a goal also reflected in the charter of the Organisation of African Unity, which states that the OAU members are:

determined to safeguard and consolidate the hard-won independence as well as the sovereignty and territorial integrity...and to fight against neocolonialism in all its forms (Charter of OAU 1963: Preamble).

Many Pan-African movements that were considered to be terrorist organisations by some influential commentators, have later become legitimate governments. After the 1969 revolution in Libya, President al-Qaddafi came into power, and in 1980 the ZANU-PF formed 
the legitimate government of Zimbabwe (Davidson 1994). In 1996 a terrorist-labelled movement, the ANC, an organisation following a pan-African ideology and led by Nielson Mandela, became the legitimate elected government in South Africa (Tambo 1988).

The US is aware of the widespread perception of neo-colonisation and states that the US is not likely to respond to challenges of instability in West Africa by deploying its own troops, and projecting an image of colonialism, "but Washington is willing to step up military aid to friendly regimes in the region" (Klare 2004). However, 'friendly regimes' are criticized by pan-African movements for playing the game of Washington, Paris and London (Ellis 2003). Several decades of armed conflicts have created a large pool of fighters with different nationalities and ethnicities, and no matter what their motivations are, they become natural allies of pan-Africanist ideologies (ibid). Public pressure from pan-African movements may force US 'friendly regimes' to make concessions to pan-African interests and to seek support from competing external powers, which may challenge US interests. Since 2003 the US has considered the islands of Sao Tome and Principle to be an appropriate place to establish a military base to safeguard and monitor its oil interests in West Africa (BBC 2003).

\section{Liberia - Challenging US Imperialism}

The Liberian conflict, which is considered to be the epicentre of destabilisation in the West Africa region, illustrates the classic debate of Liberty for the few versus Equality for the many. Liberia has for more than a century been ruled by a small elite of Americo-Liberians with close ties to the US (Johnson-Sirleaf 2006). In 1972 the President Tolbert challenged US long term hegemony in Liberia by establishing diplomatic relations with the USSR, denouncing Israel's illegal occupation of Palestine and Lebanon, supporting the independence war in Rhodesia and denying US to use Liberia for a military rapid deployment unit (Ellis 1999). Subsequently, Tolbert and 13 ministers were murdered in a military coup in 1980 lead by Samuel Doe and supported covertly by US (Mulbah 2006). The US officially supported the Doe regime but half a decade later the relationship between President Doe and the US declines. In 1985 Charles Taylor 'escaped' from a maximum security prison in Boston (Richardson 2006), and at the end of 1989 Taylor's National Patriotic Front of Liberia (NPFL) invaded Liberia, in close coordination with the US embassy in Monrovia (Taylor 2002). Less than a year later the Independent NPFL (INPFL), a break away group of the NPFL, led by General Prince Johnson captured President Doe with support from the Nigerian lead ECOMOG peacekeeping forces. General Johnson contacted the US embassy to ask what to do with President Doe but did not get any response and President Doe died in the custody of the INPFL (Johnson 2006).

Taylor broke with the US in the early 1990s and clashed with the regional mainly Anglophone peacekeeping ECOMOG, which by pan-Africanist revolutionaries was accused of prolonging a neo-colonial order in West Africa. ECOMOG was strongly opposed by

Francophone Ivory Coast and Burkina Faso, which further enforced the Anglophone/Francophone divide in Africa (Ellis 1999). Taylor won a free and fair election with more than 75 percent of the votes in 1997 (ibid). However, the relationship between the US and the government of Liberia deteriorated further, and after early 1999 the US indirectly supported the rebel group Liberian United for Reconciliation and Democracy (LURD) by supplying arms and military training to Guinea, which hosted the rebels (HRW 2003; UNHCR 2001; Richardson 2006).

Liberia is as an attractive area for oil exploration (TGS/NOPEC 2004) and in 2000 the National Oil Company of Liberia was established to deal with the highly competitive and aggressive oil industry (NOCAL 2006). However, Halliburton was denied off shore oil 
drilling concessions by President Taylor, who publicly stated that "Liberia is not for sale" because the contract was not favourable for Liberia (Dunbar 2006; Desmond 2002). The tensions between the government of Liberia and the US were reflected in a statement from the US ambassador: "Taylor has to go... The United States has a lot more involvement in Liberia than just what it does directly with its own military" (Blaney 2003).

In June 2003 the rebels attacked Monrovia and the following August Taylor went into exile in Nigeria (ACPA 2003). In 2006 Taylor was extradited to the UN-backed Special Court in Freetown was set up by the government of Sierra Leone in 2002 on recommendations of the US and UK. As Gberie (2006) notes, this court is, by many intellectuals and politicians in the region, being perceived as "selective" in the indictment and a mechanism for "global governance" which the West wants to impose worldwide. The Court is being accused for depoliticising the armed conflict in the region and the previous American chief prosecutor David Crane rejected any "injection of politics" into trials. Critics of the US/UK initiative are questioning how the court has spent more than 80 million US\$ when at the same time the Truth and Reconciliation programme was threatened because of lack of funds (TRC/SL 2003).

\section{Coercive Imposition of Neoliberal Practice}

Over a period of 25 years, three Liberian presidents, who have not been fully committed to safeguard US political and economic interests, have been killed or forced out of office. Subsequently, after Taylor went into exile in Nigeria, 15000 UN peacekeepers and 1100 international police officers were deployed under the UN Charter chapter seven in 2003 to ensure law and public order (UNMIL 2006a). It can be questioned why UN peacekeepers were not deployed in the beginning of the conflict, when the deployment could have saved thousands of lives, and why the UNSC did not put sanctions on Guinea for supporting the LURD, in accordance with the UN Charter article 24 (Charter of the UN 1945), while sanctions were enforced on Liberia for allegedly having supported the RUF in Sierra Leone (Richardson 2006).

From the perspective of the world-system analysis, it can be argued that neoliberal reconstruction takes place under the protection of UN peacekeepers, allowing the US, as the dominant power, to install an acceptable local power that must keep the country's frontiers open, be friendly toward firms based in the US, and help keep other competitive powers away from the country's natural resources (Wallerstein 2004). Or from the opposing perspective of "democratic peace", the intervention can be perceived as a force of good to promote democracy, human rights and the free market economy (US-NSR 2002). It can be argued that while "democratic peace" remains an unproven thesis (Waltz 2000), the promotion of the notion of democratic peace through the dominant media and mainstream literature, provides the incentive and justification for all international actors to converge and join forces into one Integrated 'Western' Mission. From this perspective the military, TNCs, UN agencies, local NGOs and International NGOs all become important implementation partners of the international development agenda (Corry 2006), hence forced multipliers of neoliberalism.

However, many Liberian intellectuals and politicians argue that the reconstruction programme cannot be separated from direct colonialism, imperialism and racism, which violate the Liberian Constitution (confidential source E 2006; Mulbah 2006; Taylor 2006). Those who question the intentions behind the intervention or who oppose the neoliberal development agenda are personally threatened and classified as rebels and terrorists by the Western powers (ibid). The Liberian intellectuals and politicians base their arguments on the fact that the Result Focused Transitional Framework (RFTF), which is a predecessor to the 
Interim PRSPs and the overarching Partnership framework (GEMAP 2005), have not passed the Liberian legislative power. The RFTF is monitored by the Economic Governance Steering Committee (EGSC), chaired by the national president and deputy chaired by the United States Government (EC 2006) and has been written in such a way that they do not have to pass the legislature (World Bank 2006-d). The more technical part of the RFTF is undertaken by the RFTF Implementation and Monitoring Committee (RIMCO), which is chaired by the government of Liberia and vice-chaired by the World Bank and the UN (ibid).

The transition framework is divided into four main pillars; Security, Economic Revitalization, Governance and Rule of Law and Infrastructure and Basic Services. The US controls the military power and the economic power (Richardson 2006; UNMIL 2006b). The Security Sector Reforms (SSR) is implemented by the Security Committee, which is chaired by the minister of defence and vice chaired by the United States Government (USG), UNMIL and ECOWAS (ibid). The training of the new armed forces of Liberia is undertaken by the US Private Military Corporation (PMC) Dyncorp, and the military infrastructures are undertaken by US based Pacific Architects and Engineers (Richardson 2006). Other security tasks, such as external protection of the UNMIL headquarter have been outsourced to US based security corporation Intercon (confidential source D 2006.).

The second main pillar, the Economic Revitalization Committee, is chaired by the Minister of Finance and vice chaired by the United States Government, the World Bank and the European Community. The Economic Management Assistance Programme (GEMAP) is attached to this pillar, ensuring the deployment of international recruited experts with cosignature authority in selected enterprises and institutions (GEMAP 2005). As the investment environment improves, the state owned enterprises will be privatised (EC 2006; UNDP 2006b)

The Governance and Rule of Law committee is vice chaired by the UN and the EC in partnership with the WB, UK and USG, and the Infrastructure and Basic Services committee is vice chaired by the WB and China in partnership with the UNMIL and USG (UNMIL 2006b). Most influential INGOs are represented through the Monitoring and Steering Group (MSG), which has welcomed the neoliberal RFTF (MSG 2004). According to the MSG, a closer cooperation between the INGOs and the military under the concept of Civil Military Cooperation (CIMIC) is not a question of "if" but more a question of "how" (MSG 2006). Although service sector reforms can be argued to be at the heart of the development debate, the discussion about the ahistorical neoliberal free market approach to development, versus state-led development is absent in the MSG (ibid).

In spite of the rhetoric of country ownership, participatory and voices of the poor, the drafts of the Interim PRSPs are strongly influenced by expatriates and show evidence of copy and paste from previous I-PRPS imposed on other African countries (World Bank 2006-d). The service sector reforms, which will have a direct impact on poor people's life, will follow the neoliberal direction as recommended by the World Bank (2004) and outlined in the World Development Report, "Making Services Work for the Poor". This means leaving basic services such as education and health care to a privatised competitive free market, where the client will be 'empowered' through paying for services (ibid). However, the past 25 years of experience have shown that service delivery though the free market deprives poor people of access to basic services such as basic health care (IRIN 2006; MSF 2004), arguably the most obvious violation of international law inherent in the forced imposition of neoliberal reforms. According to the International Covenant of Economic, Social and Cultural Rights article 12 (ICESCR); "The States Parties to the present Covenant recognize the right of everyone to the enjoyment of the highest attainable standard of physical and mental health". This preceding article was reaffirmed in 2002 by the UN High Commissioner for Human Rights, who added 
that, "especially for those living in poverty, this goal is becoming increasingly remote" (UNHCHR 2002: Preamble).

If the common people do not have access to their basic socio-economic rights and do not benefit from development, they may easily be encouraged to take up arms again (MODEL 2006). Armed groups fighting against any external dominating power naturally sympathise with the pan-African ideology (Ellis 2003). These concerns seem to be shared by the International Crisis Group, which states that "it is a very fine balance between intrusive and overbearing... we are always going to be sensitive to charges of neo-colonialism, imperialism and racism (McGovern 2005,).

\section{CONCLUSION}

The mind frame that perceives neoliberalism and the international development agenda as a benevolent project, being both pro-democratic and pro-poor, and as a prerequisite for sustainable development, gives rise to a number of paradoxes, which have been pointed out in this paper. Identifying the original liberal ideologies and analysing neoliberalism from a world-historical perspective brings us back to the classical debates on the balance between liberty and equality, on how to redistribute resources and on what kind of development is desirable as a long term vision.

In spite of many attempts to prove that the neoliberal approach to development works, the global figures on poverty and mortality in the neoliberal era provide evidence that something is clearly wrong. Many influential commentators, such as Dollar and Kraay (2001) claim that neoliberal globalisation in the past two decades has contributed to narrowing the gap between rich and poor worldwide. In contrast, a comprehensive study by the ILO (2005) indicates that the gap between rich and poor has increased significantly since 1980. As Milanovic (2003) points out, the countries that by the World Bank and the IMF have been praised as the best model reformers, and that have followed several structural adjustment programmes, find themselves in crisis with their GDPs halved and in need of debt forgiveness.

Cheng's argument, that the neoliberal international development agenda and the PRSPs "kicks away the ladder" and deprive weaker states from development may appear as cynical to some people and these arguments are likely to be neglected or completely rejected by the proponent of neoliberalism and the democratic peace thesis. Nevertheless, much indicates that the end of the Cold War was as a change in the world system and not of the world system as Waltz (2000) argues, hence realism remains the dominant theory in international relations. This automatically brings back the more grim theories on imperialism and neo-colonialism, including the important theoretical frameworks of dependency theory and World-Systems Analysis, from where relationships between strong and weak states can be analysed.

But these theories present the world as consisting of selfish people and states struggling for power and wealth through domination and exploitation of other people and weaker states, and where the political and economic interests of the strong states are endangered, military force will be applied, disguised in a political rhetoric of human rights and democracy to gain popular domestic support. However, by relating the end of the Cold War to Fukuyama's "End of History", which indirectly declares realism for 'dead', the liberal democratic peace theory has become a seductive and useful tool to vilify dissenting groups as terrorists, justify increasing surveillance of populations and legitimise military interventions in the name of democracy, human rights and free market economy. 
While realism and imperialism will continue to dominate in practice, the rhetoric of democratic peace will dominate the mainstream media and literature to manufacture public consent. However, because neoliberalism pulls societies away from democratisation despite its proponents claims that it is an instrument for the promotion of democracy (Radice 2005), and because it attacks the public sector as a whole, social movements have arisen that aim to reconstitute a regulatory and redistributive state, which is opposite to neoliberalism (Bourdieu 2001). Civil societies offer alternative politics of accountability (Sinha 2005), and as Deacon (1997) points out, there is a growing number of social movements, which aim towards longterm visions of a global welfare state, founded on the principles of a sound balance between Liberty and Equality.

\section{Acknowledgement}

I would like to thank all those persons from; the Government of Liberia, the Liberian Legislature, civil society organisations, international organisations, former combatants and military commanders, whom I have interviewed during my field research in Liberia between June and July 2006.

The outspokenness of all interviewed people, several of whom must remain anonymous in this article for security reasons, has contributed significantly to this paper. 


\section{REFERENCES}

Accra Comprehensive Peace Accord (ACPA). 2003. Peace Agreement Between the Government of Liberia, (GOL), The Liberians United for Reconciliation and Democracy (LURD), The Movement for Democracy in Liberia (MODEL) and the Political Parties. Accra, Ghana, 18th August 2003. Retrieved on December 8, 2007. (http://www.usip.org/library/pa/liberia/liberia_08182003_toc.html)

Amin, Samir. 2006. Beyond US Hegemony? - Assessing the Prospects for a Multipolar World. Zed Books Ltd, London, 2006

Arestis, Philip and Sawyer, Malcolm. 2005. "Neoliberalism and the Third Way." Pp. 177-183 in Neoliberalism, A Critical Reader, edited by Saad-Filho, Alfredo and Johnston, Deborah. London: Pluto Pres.

Archibugi, Daniele. 2004. "Cosmopolitan Democracy and its Critics: A Review." London School of Economics and Political Science, London, UK and Italian National Research Council, Italy. Retrieved on December 8, 2007. (http://www.danielearchibugi.org/papers/index.htm\#theory)

Arendt, Hannah. 1969. "Reflection on Violence." New York Review of Books, 27 February, 1969.

Arrighi, Giovanni and Moore W. Jason. 2001. Capitalist Development in World Historical Perspective. Pp. 56-75 in Phases of Capitalist Development: Booms, Crisis and Globalizations, edited by Albritton, R., Itoh, M., Westra, R. and Zuege, A.: New York. Palgrave

Barlow, Maude and Tony Clarke. 2002. Blue Gold: The Fight to Stop the Corporate Theft of the World's Water. New Press, 2002

BBC (2003). Oil Key to Sao Tome. BBC, 16 July, 2003. Retrieved December 8, 2007. (http://news.bbc.co.uk/2/hi/africa/3070813.stm)

Baran, Paul. 1957. Pp. 43 in Dependency Theory: A critical Reassessment. Palma, Gabriel. 1981: Francis Pinter, 1981.

Blackburn, Robin. 2002. "Globalisation and its discontents by Joseph Stiglitz". Review in the Independent, August $\quad 10,2002 . \quad$ (http://www.arlindocorreia.com/globalization_stiglitzs_case.html\#Globalisation)

Blaney, John. 2003. John Blaney, US Ambassador to Liberia, since September 2002. Interviewed in Jonathan Stack's documentary "Liberia, and Uncivil War": Gabriel Films, 2003

Bourdieu, Pierre. 1991. Language \& Symbolic Power. Polity Press. . 2001. Retaliation: Hans Reitzels Forlag, Copenhagen.

Braudel, Fernand. 1963. A History of Civilizations. London. Penguin Books.

Briggs, A .1961. The Welfare State in Historical Perspective. European Journal of Sociology 2. Pp. $221-58$

Brown, Mallock M. 2006. "UN Needs U.S., U.S. Needs UN to Face Challenges - HIV/AIDS, Sudan -- That Defy. National Solutions, Says Deputy Secretary General in New York Address." Deputy Secretary-General DSG/SM/287: UN Department of Public Information. News and Media Division. 7 June 2006. New York.

Bush, George. 2007. State of the Union 2007. The White House. Retrieved December 8, 2007.

(http://www.whitehouse.gov/news/releases/2007/01/20070123-2.html)

. 2004. Do democracies fight each other? BBC, November 17, 2004. Retrieved on December 8, 2007. 
(http://news.bbc.co.uk/2/hi/uk_news/magazine/4017305.stm) . 2003. Bush's speech. A transcript of George Bush's war ultimatum speech from the Cross Hall in the White House. Guardian, March 18, 2003. Retrieved on December 8, 2007. (http://www.guardian.co.uk/Iraq/Story/0,,916543,00.html)

Cammack, P. 2004. "What the World Bank Means by Poverty Reduction, and Why if Matters." New Political Economy: Vol. 9, No. 2.

Chandler, David. 2000. "International Justice." New Left Review. November-December 2000. Retrieved on December 8, 2007. (http://newleftreview.org/A2287)

Chang, Ha Joon. 2003. Kicking Away the Ladder - development Strategy in Historical Perspective: London. Anthem Press.

Chang, Ha-Joon and Ilene Grabel. 2004. Reclaiming Development; An alternative economic policy manual. Fernwood Publishing Ltd.

Charter of the Organisation of Africa Unity 1963. Retrieved December 8, 2007. (http://www.oau-creation.com/OAU\%20Charter.htm)

Charter of the UN 1945. Retrieved December 8, 2007. (http://www.un.org/aboutun/charter/index.html)

Chomsky, Noam. 2000. Rogue States: The Rule of Force in World Affairs. Pluto Press 2000 . 2002. Media Control - The Spectacular Achievements of Propaganda. New York: Seven Stories Press. Open Media Pamphlet Series.

Church Committee. 1975. United States Senate Select Committee to Study Governmental Operations with Respect to Intelligence Activities. AARC Public Library Contents. $\begin{array}{llll}\text { Retrieved on } & \text { December } & \end{array}$ (http://www.aarclibrary.org/publib/church/reports/contents.htm)

CIA. 1999. Central Intelligence Agency. Interview with CIA chief in the Congo Larry Devlin, in Thierry Michel documentary "Mobutu, King of Zaire". Cinélibre. Brussels.

Corry, Peter. 2006. Head of Civil Military Cooperation (CIMIC). Interview recorded July 11, 2006, in Monrovia by Hahn N. (nsc.hahn@gmail.com).

Clinton, William J. 1994. Address Before a Joint Session of the Congress on the State of the Union, January 25, 1994. Retrieved on December 8, 2007.

(http://frwebgate.access.gpo.gov/cgibin/getdoc.cgi?dbname=1994_public_papers_vol1_text\&docid=pap_text-64.pdf)

Colás, Alejandro. 2005. "Neoliberalism, Globalisation and International Relations." Pp. 7079, in Neoliberalism, A Critical Reader, edited by Saad-Filho, Alfredo and Johnston, Deborah. London: Pluto Pres.

Collier, Paul and Anke Hoeffler. 2002. "On the Incidence of Civil War in Africa". The Journal of Conflict Resolution, Vol. 46, No. 1, Understanding Civil War. (Feb., 2002) pp. 13-38.

Confidential source A. 2007. High Positioned Advisor to the Executive Mansion, Republic of Liberia. Name kept confidential for security reasons. Interview recorded June 19, 2006, in Monrovia by Hahn N. (nsc.hahn@gmail.com).

Confidential source B. 2007. Intellectual person from Darfur, well connected to different rebel groups and the government of Sudan. Name kept confidential for security reasons. Interviewed in Nyala, March, 2007. Name of interviewer kept confidential due to ethical considerations.

Confidential source C. 2007. Intellectual person from Darfur well connected to the government of Sudan and the main opposition groups to the government. Name kept confidential for security reasons. Interviewed in Khartoum, April 2, 2007. Name of interviewer kept confidential due to ethical considerations. 
Confidential source D. 2006. Employee of Intercon working at the UNMIL headquarter in Monrovia. Name kept confidential for security reasons. Interviewed by Hahn N. in Monrovia, July 6, 2006. (nsc.hahn@ gmail.com).

Confidential source E. 2006. High ranking politician in Monrovia, and former Minister during President Tolbert's administration. Name keep confidential upon request due to personal security. Interview June 30, 2006, in Monrovia by Hahn N. (nsc.hahn@gmail.com).

Cooper, Robert. 2002. "Why we still need empires." Guardian, April the 7, 2002. Retrieved on December 8, 2007. (http://observer.guardian.co.uk/worldview/story/0,11581,680117,00.html)

Cox, Michael. 2003. "The Empire's Back in Town: Or America's Imperial Temptation Again.” Journal of International Studies. ISSN 0305-8298. Vol. 32, No. 1, pp. 1-27.

Dallaire, Romeo. 2003. Shake Hands With the Devil: The Failure of Humanity in Rwanda 2003. Canada: Knopf.

Davidson, Basil. 1994. Modern Africa: A Social and Political History. $3^{\text {rd }}$ edition. Longman.

Deacon, Bob. 1997. Global Social Policy. International organizations and the Future of Welfare. London: Sage Publications Ltd.

Desai, Radhika .2004. "From national bourgeoisie to rogues, failures and bullies: 21st century imperialism and the unravelling of the Third World." Third World Quarterly. Vol 25, No 1, pp 169-185, 2004

Deshield, Leonard and Sadie. 1999. Beneath the Cold War: The Death of a Nation. Professionals Press Publishers, 1999

Desmond, Davis. 2002. Editor of West Africa magazine, 26th May-1st June 2002.

Dollar, David \& Kraay, Aart. 2001. "Trade, Growth, and Poverty. Finance \& Development." Finance \& Development, A quarterly magazine of the IMF. September 2001, Volume 38 , number 3 .

Duménil Gérard \& Lévy Dominique. 2005. "The Neoliberal (Counter-) Revolution.” Pp. 9-19 in Neoliberalism, A Critical Reader, edited by Saad-Filho, Alfredo and Johnston, Deborah. London: Pluto Pres.

Dunbar, Jenkins. 2006. Former Minister of Land, Mines and Energy, Republic of Liberia. Interview recorded in Monrovia by Hahn, N. June 16, 2006. (nsc.hahn@gmail.com).

ECOSOC. 2006. UN Economic and Social Council. Background. Retrieved December 8, 2007. (http://www.un.org/docs/ecosoc/ecosoc_background.html)

Elliott, Larry .2003. "The Lost Decade.” Global Policy Forum. Retrieved on December 8, 2007. (http://www.globalpolicy.org/socecon/un/2003/0709lost.htm)

Ellis, Stephen. 1999. The Mask of Anarchy: The Destruction of Liberia and the Religious Roots of an African Civil War. London: Hurst

. 2003. "International Elements of West Africa's Wars: The role of sub-regional and non-African Actors". OECD, Paris, May 2003. Conflict and Development Policy in the Mano River Region and Cöte d'Ivoire: The Regional Stakes for Stability and Reconstruction.

Evans, Tony. 2001. "If Democracy, Then Human Rights?" Third World Quarterly. Vol 22, No 4, 2001 pp. $623-642$ . 2002. "A human right to health?" Third World Quarterly. Vol 23, No 2, pp. 197 215.

EC. 2006. European Commission in Liberia. Gabelle, Christopher. Development \& Governance Adviser. Office of the European Commission in Liberia. Interview recorded in Monrovia by Hahn, N. July 6, 2006. (nsc.hahn@ gmail.com).

Falk, Richard. 2003. The Great Terror War. New York: Olive Branch Press. 


\section{JOURNAL OF WORLD-SYSTEMS RESEARCH}

Fanon, Frantz. 1963. The Wretched of the Earth. Translated by Richard Philcox. New York: Grove Press.

Feinstein Institute. 2005. "The Humanitarian Agenda 2015: Politics, Power and Perceptions." The Alan Shawn Feinstein International Famine Center. Retrieved December 8, 2007. (http://fic.tufts.edu/?pid=32)

Fine, B \& Alfredo Saad-Filho. 2006. Marx's Capital. London: Pluto Press

Fineman, Mark. 1993. “The Oil Factor in Somalia.” Los Angeles Times, January 18, 1993. Retrieved on December 8, 2007. (http://www.netnomad.com/fineman.html)

Frank, Andre Gunder. 1967. Capitalism and Underdevelopment in Latin America. New York: Monthly Review Press 1967, revised ed. 1969. London: Penguin Books 1971.

Fraser, Ian. 2002. "World Bank rebel wages war on Wall Street". Sunday Herald, July, 7, 2002. (http://www.ianfraser.org/?p=41)

Freeman, Chas. W. 2000. "The United States and Saudi Arabia: American Interests and Challenges to the Kingdom in 2002." Middle East Policy Council - Twenty-seventh in the Capitol Hill Conference Series on U.S. Middle East Policy. Retrieved on December 8, 2007. (http://www.mepc.org/forums_chcs/27.asp)

Fukuyama, Francis. 1989. "The End of History?, The National Interest, Summer 1989." Retrieved on December 8, 2007. (http://www.sais-jhu.edu/faculty/fukuyama/publications.html) 2006. The End of History and the Last Man. NY: Free Press, a Division of Simon \& Schuster, Inc.

Gedi, Mohamed. 2006. "U.S. Secretly Backing Warlords in Somalia." Statement by Prime Minister of Somalia transitional government, Ali Mohamed Gedi. Washington Post, May 17, 2006. Retrieved on December 8, 2007.

(http://www.washingtonpost.com/wpdyn/content/article/2006/05/16/AR20060516016 25.html)

GEMAP. 2005. Governance and Economic Management Assistance Program. Done at Monrovia (Liberia) 9 day of September 2005.

Gibrie, Lansane. 2006. "Sierra Leone, Trial of a 'war hero'." Znet, March 10, 2006. Retrieved June 8, 2007. (http://www.zmag.org/content/showarticle.cfm?ItemID=9888)

Giddens, Anthony. 1998. The Third Way. The Renewal of Social Democracy. London: Polity Press in association with Blackwell Publisher Ltd.

Gokay, Bulent. 2006. "Iraq, Iran and the end of petrodollar: The warning influence of the USA in the Asian Century." Pravda 15 May, 2006. Retrieved on December 8, 2007. (http://english.pravda.ru/opinion/feedback/80289-0/)

Gowan, Peter. 2004. "Contemporary Intra-Core Relations and World Systems Theory". Journal of World Systems Research. Volume X, Number 2. Summer 2004. Retrieved on February 14, 2008.

(http://jwsr.ucr.edu/archive/vol10/number2/pdf/jwsr-v10n2gs-gowan.pdf)

Harvey, David. 2003. The New Imperialism. New York: Oxford University Press . 2005. A Brief History of Neoliberalism. New York: Oxford University Press Inc.

Hoyos, Carola and Kevin Morrison. 2003. Iraq returns to international oil market. Financial Times, June 5, 2003. Retrieved on December 8, 2007.

(http://www.thedossier.ukonline.co.uk/Web\%20Pages/FINANCIAL\%20TIMES_Iraq\%20retu rns\%20to\%20international\%20oil\%20market.htm)

Human Rights Watch. 2003. "Weapons Sanctions, Military Supplies, and Human Suffering: Illegal Arms Flows to Liberia and the June-July 2003 Shelling of Monrovia." Human Rights Watch. Retrieved on December 8, 2007. (http://hrw.org/backgrounder/arms/liberia/liberia_arms.pdf) 
Huntington, Samuel. 1993. "The Clash of Civilizations?" Foreign Affairs, Vol.72, No.3, pp.22-49.

ICCPR. 1966. International Covenant of Civil and Political Rights. UNHCHR. Retrieved on December 8, 2007. (http://www.unhchr.ch/html/menu3/b/a_ccpr.htm)

ICESCR. 1966. International Covenant of Economic, Social and Cultural Rights. UNHCHR. Retrieved on December 8, 2007. (http://www.unhchr.ch/html/menu3/b/a_cescr.htm)

ICISS. 2001. The Responsibility to Protect. Report of the International Commission on Intervention and State Sovereignty. Retrieved on December 8, 2007. (http://www.iciss.ca/menu-en.asp)

ICJ. 1986. International Court of Justice. Case Concerning the Military and Paramilitary Activities in and Against Nicaragua (Nicaragua v. United States of America. International Court of Justice. Retrieved on December 8, 2007. (http://www.icjcij.org/docket/index.php?sum=367\&code=nus\&p1=3\&p2=3\&case=70 $\& \mathrm{k}=66 \& \mathrm{p} 3=5)$

ILO. 2005. International Labour Organisation. Key Indicators of the Labour Market, Fourth Edition. ILO. Retrieved on December 8, 2007. (http://www.ilo.org/public/english/employment/strat/kilm/)

ICG. 2007. International Crisis Group. Crisis in Darfur, What needs to be done. Retrieved on December 8, 2007. (http://www.crisisgroup.org/home/index.cfm?id=3060\&l=1\#C3)

IRIN. 2006. IRIN news - UNOCHA. Killer Number One: The fight against malaria, IRIN InBepth - Artemisinin: the drug that cannot afford to fail. Retrieved on December 8, 2007. (http://www.irinnews.org/webspecials/malaria/51345.asp)

Johnson, Prince Y. 2006. Former leader of the Independent National Partriotic Front of Liberia (INPFL). Present, Senior Senator for Nimba County, Republic of Liberia and Chairman - National Security \& Intelligence. Interview recorded July 5, 2006, in Monrovia by Hahn N. (nsc.hahn@gmail.com).

Johnston, Deborah. 2005. Poverty and Distribution: Back on the Neoliberal Agenda? Pp. 135141, in Neoliberalism, A Critical Reader, edited by Saad-Filho, Alfredo and Johnston, Deborah. London: Pluto Pres.

Johnson-Sirleaf, Ellen. 2006. Speech at the International Institute For Strategic Studies, 31 May, 2006, London. Speech recorded and can be retrieved at: (nsc.hahn@gmail.com).

Juhasz, Antonia. 2006. The Bush Agenda - Invading The World, One Economy At The Time. London: Gerald Duckworth \& Co. Ltd.

Kaldor, Mary. 1999. New \& Old Wars - Organized Violence in a Global Era. London: Blackwell Publishing Ltd, 2004.

Kant, Immanuel. 1795. Perpetual Peace: A Philosophical Sketch. Mount Holyoke. Retrieved on December 8, 2007. (http://www.mtholyoke.edu/acad/intrel/kant/kant1.htm)

Kaplan, R. 1994, "The Coming Anarchy: how scarcity, crime, overpopulation and disease are rapidly destroying the social fabric of our planet." The Atlantic Monthly, February, pp.44-74. Retrieved on December 8, 2007. (http://www.theatlantic.com/doc/prem/199402/anarchy)

Khan, Mary. 1997. "State Failure in Weak States: A Critique of New Institutionalist Explanations." Pp. 71-86 in The New Institutional Economics and the Third World Development, edited by Johan Harris et al. London: Routledge.

Khan, H. Mushtaq. 2002. "State Failure in Developing Countries and Strategies of Institutional Reforms". Paper for ABCDE Conference, Oslo June 2002. Department of Economics, SOAS, University of London. Retrieved on December February 14, 2008. 
(http://wbln0018.worldbank.org/eurvp/web.nsf/Pages/paper+by+Mushtaq+Khan/\$Fil e/KHAN+STATE+FAILURE.PDF)

Klare, Michael. 2004. Bush-Cheney Energy Strategy: Procuring the Rest of the World's Oil. Thinking Peace. Retrieved on December 8, 2007. (http://www.thinkingpeace.com/pages/Articles/arts129.html)

Koulibaly, Mamadou. 2006. Côte d' Ivoire, 'It is an economic war orchestrated by France'. Interview in by Ruth Tete. New African, July 2006, no 453

Lapavitsas, Costas. 2005. "Mainstream Economics in the Neoliberal Era". Pp. 30-40, in Neoliberalism, A Critical Reader, edited by Saad-Filho, Alfredo and Johnston, Deborah. London: Pluto Pres.

League of Nations. 1930. In Toporowski, Jan (2005). "A Haven of Familiar Monetary Practice: The Neoliberal Dream in International Money and Finance." Pp. 106-112, in Neoliberalism, A Critical Reader, edited by Saad-Filho, Alfredo and Johnston, Deborah. London: Pluto Pres.

Leys, Colin 1996. The Rise and Fall of Development Theory. EAEP, Nairobi: Indiana University Press. James Currey, London.

Mabee, Bryan 2004. "Discourses of Empire: the US 'empire', globalisation and international relations." Third World Quarterly, Vol. 25, no. 8, pp. 1359 - 1378.

MacEwan, Arthur. 2005. Neoliberalism and Democracy: Market Power versus Democratic Power. Pp. 170-176, in Neoliberalism, A Critical Reader, edited by Saad-Filho, Alfredo and Johnston, Deborah. London: Pluto Pres.

MacGregor, Susanne (2005). The Welfare State and Neoliberalism. Pp. 142-148, in Neoliberalism, A Critical Reader, edited by Saad-Filho, Alfredo and Johnston, Deborah. London: Pluto Pres.

McNamara, Robert S. 2003. Former US Secretary of Defense from 1961 to 1968. Interviewed in Errol Morris's documentary "The Fog of War": Sony Pictures Classics, 2003.

Macrae, Joanna. 1996. NGOs: Has the 'N' gone missing? International Red Cross and Red Crescent Movement. Retrieved on December 8, 2007. (http://www.redcross.int/EN/mag/magazine1996_3/18-19.html)

Mazurovski, Marc. 2005. In the documentary, Point du Jour, Pacte Avec Le Diable (1x52'), Réal : Steve Baumann, (In pact with the devil). Broadcasted the $4^{\text {th }}$ of April 2006 by Danmarks Radio, DR2, Tyge Petersen. Retrieved on December 8, 2007. (http://www.tvfranceintl.com/tvfi/direct_societe.php?idsoc=79\&langue=An\&nom=P OINT+DU+JOUR++INTERNATIONAL)

Mamdani, Mahmood. 2007. The Politics of Naming: Genocide, Civil War, Insurgency. London Review Bookshop. Retrieved June 8, 2007. (http://www.lrb.co.uk/v29/n05/mamd01_.html)

Mann, Michael. 1999. "The Dark Side of Democracy: The Modern Tradition of Ethnic and Political Cleansing". New Left Review, no. 235 2003. Incoherent Empire. London: Verso.

McChesney, Robert W. 1999. "Introduction". Pp. 7-16, in Profit Over People: Neoliberalism and the Global Order. Chomsky N. (1999). New York: Seven Stories Press.

McGovern, Mike. 2006. International Crisis Group (ICG), Program Director for West Africa. "Liberia's daunting new beginning, First female president in Africa faces effects of war and deep corruption." San Francisco Chronicle, Foreign Service, January 15, 2006.

Mearsheimer, John J. 1995. "The False Promise of International Institutions." International Security, Vol. 19, No. 31, pp. 5 - 49. 
Milanovic, Branko. 2003. "The Two Faces of Globalization: Against Globalization as We Know It." World Development, Vol. 31, No. 4, pp. 667 - 683.

MODEL .2006. Movement for Democracy in Liberia. Group of eight Ex-combatants. Names and rank confidential. Interview recorded July 23, 2006, in Monrovia by Hahn N. (nsc.hahn@gmail.com).

Morgenthau, Hans J. 1978. Politics Among Nations - The Struggle for Power and Peace. Seventh Edition. Revised by Kenneth W. Thompson and W. David Clinton, 2006. McGraw-Hill 2006

MSF. 2004. Médecins sans Frontières. "No cash, no care. MSF's confrontation with cost recovery.” International Activity Report 2004, Brussels. Retrieved on December 8, 2007.

(http://www.doctorswithoutborders.org/publications/ar/i2004/costrecovery.cfm)

MSG. 2004. Monitoring \& Steering Group (a consortium of 35 INGOs operating in Liberia). Remarks prepared by the Monitoring \& Steering Group. Address given by Nicky Smith, The IRC Liberia Country Director, on behalf of the MSG, 2004. Can be retrieved at: (nsc.hahn@gmail.com)

. 2006. Monitoring \& Steering Group (a consortium of INGOs operating in Liberia). Isabelle Marie, INGO Liaison Officer, MSG. Interview recorded July 18, 2006, in Monrovia by Hahn N. (nsc.hahn@ gmail.com).

Mulbah, Joe W. 2006. Former Minister of Information, Republic of Liberia. Ass. Professor in Mass Communication, University of Liberia. Interview recorded June 27, 2006, in Monrovia by Hahn N. (nsc.hahn@gmail.com).

Nahory, Céline. 2004. "The Hidden Veto." Global Policy forum. Retrieved on December 8, 2007. (http://www.globalpolicy.org/security/veto/2004/0519hiddenveto.htm)

Nanga, Jean. 2005. "A 'Civil War' that is French and Neo-Colonial." IV Online magazine: IV364 - February 2005. Retrieved on December 8, 2007. (http://www.internationalviewpoint.org/spip.php?article553).

NEP. 2001. "Report of the National Energy Policy Development Group." Government of the United States. Retrieved on December 8, 2007.

(http://www.whitehouse.gov/energy/National-Energy-Policy.pdf)

Nkrumah, Kwame (1965), Neo-Colonialism: The Last Stage of Imperialism. Intl Pub . 1973. Revolutionary Path. London: Panaf Books

NOCAL. 2006. National Oil Company of Liberia. Management Briefing to the Board of Directors of NOCAL, April 2006, Monrovia, Liberia. Can be retrieved at: (nsc.hahn@gmail.com).

OHCHR. 2006. Office of the United Nations High Commissioner for Human Rights. Ratifications and Reservations. Retrieved on December 8, 2007. (http://www.unhchr.ch/tbs/doc.nsf)

Palley, I. Thomas. 2005. "From Keynesianism to Neoliberalism: Shifting Paradigms in Economics." Pp. 20-29, in Neoliberalism, A Critical Reader, edited by Saad-Filho, Alfredo and Johnston, Deborah. London: Pluto Pres.

Parenti, Michael. 1995. Against Empire. City Lights Publishers. San Francisco.

Pentagon. 2007. US 'targets al-Qaeda' in Somalia. BBC, January 9, 2007. Retrieved on December 8, 2007. (http://news.bbc.co.uk/2/hi/africa/6245943.stm)

Pilger, John. 2002. The New Rulers of the World. Verso Books

Powel, Collin. 2001. In Rony Brauman \& Pierre Salignon; Iraq: in Search of a "Humanitarian Crisis". MSF, April 16, 2004. Retrieved on December 8, 2007.

(http://www.doctorswithoutborders.org/publications/ideas/opinion_ronybrauman.cfm 
Project for the New American Century. 1997. Statement of Principles and About PNAC. Retrieved on December 8, 2007 (http://www.newamericancentury.org/)

Radice, Hugo (2005). "Neoliberal Globalisation: Imperialism without Empires?". Pp. 91-98, in Neoliberalism, A Critical Reader, edited by Saad-Filho, Alfredo and Johnston, Deborah. London: Pluto Pres.

Rashid, Ahmed. 2001. Taliban: Militant Islam, Oil and Fundamentalism in Central Asia. Yale University Press 2001

Richardson, John. 2006. Former National Security Advisor of Liberia. In interview given the 17 June, 2006. Interview recorded June 27, 2006, in Monrovia by Hahn N. (nsc.hahn@gmail.com).

Robinson, William. 2004. A Theory of Global Capitalism: Production, Class and State in a Transnational World. Maltimore, MD: John Hopkins University Press, 2004.

Said, Edward W. 1999. "Apocalypse Now." In Acts of Aggression. Noam Chomsky \& Edward W. Said. Open Media Pamphlet, 1999

Sartra, Jean-Paul. 1961. Pp. xliii- lxii in The Wretched of the Earth. Frantz Fanon, 1961. Translation from the French by Richard Philcox. New York, Grove Press.

Save Darfur. 2007. Take Action. Retrieved on December 8, 2007. (http://www.savedarfur.org/section/take_action)

Schwartz, Thomas and Kiron Skinner. 1999. The Myth of Democratic Pacifism." Hoover Institution. Hover Digest 1999 No. 2

Sinha, Subir. 2005. "Neoliberalism and Civil Society: Project and Possibilities". Pp. 163-169, in Neoliberalism, A Critical Reader, edited by Saad-Filho, Alfredo and Johnston, Deborah. London: Pluto Pres.

Smith Adam. 1776. An Inquiry into the Wealth of Nations. MetaLibri. Retrieved on December 8, 2007.

(http://metalibri.incubadora.fapesp.br/portal/authors/AnInquiryIntoTheNatureAndCau sesOfTheWealthOfNations).

Stiglitz, Joseph. 2002. Globalization and its discontents. Penguin Books Ltd. . 1998. More Instruments and Broader Goals: Moving Toward the Post-Washington Consensus. The 1998 WIDER Annual Lecture. Helsinki, Finland, January 7, 1998. Retrieved on December 8, 2007. (http://www2.gsb.columbia.edu/faculty/jstiglitz/papers.cfm).

Stockwell, John. 1992. Former CIA Station Chief in Angola. Interviewed in the documentary "Black Power", written and produced by Adam Curtis. BBC. Pandora's Box. 1992. . 1991. The Praetorian Guard: The US Role In The New World Order. Boston: South End Press.

Stokes, Doug. 2005. "The Heart of Empire? Theorising US empire in and era of transnational capitalism." Third World Quarterly, Vol. 26. No. 2, pp 217 - 236, 2005.

Saad-Filho, Alfredo \& Johnston, Deborah (2005). "Neoliberalism, A Critical Reader, Introduction." Pp. 1-6, in Neoliberalism, A Critical Reader, edited by Saad-Filho, Alfredo and Johnston, Deborah. London: Pluto Pres.

. 2005. "From Washington to Post-Washington Consensus: Neoliberal Agendas for Economic Development.” Pp. 113-119, in Neoliberalism, A Critical Reader, edited by Saad-Filho, Alfredo and Johnston, Deborah. London: Pluto Pres.

Tambo, Oliver. 1988. Interview to the Times, London, June 13, 1988. African National Congress (ANC). Retrieved on December 8, 2007. (http://www.anc.org.za/ancdocs/history/or/pr/lond88.html)

Taylor, Charles. 2002. Charles Taylor speaks. Interview by Baffour Ankomah, New African, July/August 2002. No 409. 
Taylor, Jewel H. 2006. Senior Senator, Bong County. Chairperson, Senate Committee on Health \& Social Welfare and Health \& Social Welfare. Former First Lady of Liberia. Interview recorded July 10, 2006, in Monrovia by Hahn N. (nsc.hahn@ gmail.com).

TGS-NOPEC. 2004. TGS-NOPEC Geophysical Company. Liberia, Petroleum Exploration Opportunities \& Potential.

Thomas, Alan. 2000. "Development as Practise in a Liberal Capitalist World." Journal of International Development. J. Int. Dev. 12, 773 - 787 (2000)

Toporowski, Jan. 2005. "'A Haven of Familiar Monetary Practise': The Neoliberal Dream in International Money and Finance." Pp. 106-112, in Neoliberalism, A Critical Reader, edited by Saad-Filho, Alfredo and Johnston, Deborah. London: Pluto Pres.

TRC/SL. 2003. Truth and Reconciliation Commission in Sierra Leone. TRC Documents, Volume 2. Retrieved on December 8, 2007. (http://trcsierraleone.org/drwebsite/publish/index.shtml)

UDHR. 1948. Universal Declaration of Human Rights. United Nations. Retrieved on December 8, 2007. (http://www.unhchr.ch/udhr/index.htm)

UN. 2004. Report of the Open-ended Working Group on the Question of Equitable Representation on the Increase in Membership of the Security Council and Other Matters related to the Security Council. UN New York, 2004. Retrieved on December 8, 2007. (http://www.unis.unvienna.org/unis/pressrels/2002/ga10039.html)

UN General Assembly Resolutions. 1974. Declaration on the Establishment of a New International Economic Order (1 May 1974). A/RES/3201(S-VI). Retrieved on December 8, 2007. (http://www.un.org/Depts/dhl/resguide/resins.htm)

UNCTAD. 2002. United Nations Conference on Trade and Development, Geneva. "Economic Development in Africa. From Adjustment to Poverty Reduction: What is New?" United Nations. Retrieved June 8, 2007. (http://www.unctad.org/en/docs/pogdsafricad2.en.pdf).

UNDP. 2002. "The Millennium Development Goals." United Nations. Retrieved on December 8, 2007. (http://www.un.org/Pubs/CyberSchoolBus/mdgs/goal1.asp) . 2006a. United Nations Development Programme. "Human Development Report 2006. Beyond scarcity: Power, poverty and the global water crisis". United Nations. Retrieved on February 14, 2008 (http://hdr.undp.org/en/reports/global/hdr2006/) 2006b. United Nations Development Programme. "Results Focused Transitional Framework For Liberia (RFTF)" Satya S. Tripathi, International Policy \& Aid Coordination Advisor Energy and Environment - Interview recorded July 3, 2006, in Monrovia by Hahn N. (nsc.hahn@gmail.com).

UNGA. 1974. United Nations General Assembly. Declaration on the Establishment of a New International Economic Order. United Nations Resolutions adopted by the General Assembly. A/Res/S-6/3201 (S-VI). (http://www.un-documents.net/s6r3201.htm)

UNHCHR. 2002. "Commission on Human Rights resolution 2002/31" United Nations. Retrieved on December 8, 2007.

(http://www.unhchr.ch/Huridocda/Huridoca.nsf/0/5f07e25ce34edd01c1256ba60056d eff?Opendocument)

UNHCR. 2001. "West Africa: Problems \& Prospects for Stability in the Mano River States." Centre for Documentation and Research. Kamara, Tom, Independent Researcher, The Netherlands. Writenet Paper No. 02/2001.

Retrieved on December 8, 2007. (http://www.unhcr.org/publ/RSDCOI/3c4bf7c07.pdf)

UNICEF. 2006. The Big Picture. United Nations. Retrieved on December 8, 2007. (http://www.unicef.org/earlychildhood/index_bigpicture.html) 
UNMIL. 2006a. United Nations Mission in Liberia. UNMIL, Background. United Nations. Retrieved on December 8, 2007. (http://www.un.org/Depts/dpko/missions/unmil/background.html)

. 2006b. United Nations Mission in Liberia - Chart of Liberia Reconstruction and Development Committee (LRDC). United Nation. Document can be retrieved at (nsc.hahn@gmail.com)

UNOCHA. 2006. IRIN Web Special: Somali National Peace Conference. IRIN News. Retrieved on December 8, 2007.

(http://www.irinnews.org/InDepthMain.aspx?InDepthId=54\&ReportId=72043)

. 2007. High ranking OCHA representative in Darfur. Names and information retrieved is kept confidential due to ethical considerations.

UNSC. 1990. United Nations Security Council, 16 - Jan - 1990. Draft S/21084. Meeting no. 2905. Retrieved on February 14, 2008. (http://www.globalpolicy.org/security/membship/veto/s21084.htm)

US Embassy Mogadishu. 1990. Cable from US Embassy in Mogadishu to State Department Headquarters. 21 March 1990. Cable Number: Mogadishu 02844. Freedom of Information Act release 2006-01-286 to Keith Yearman. Retrieved on 14 February 2008.

US National Security Report. 2002. "The National Security Report of the United States of America." White House, Washington, 2002

US State Department. 2006. "Foreign Relations of the United States 1964 - 1968." Volume XXIV, Africa, Department of State. Retrieved on December 8, 2007. (http://www.state.gov/www/about_state/history/vol_xxiv/x.html).

Veltmeyer, Henry and James Petras. 2005. "Foreign Aid, Neoliberalism and US Imperialism.” Pp. 120-126, in Neoliberalism, A Critical Reader, edited by SaadFilho, Alfredo and Johnston, Deborah. London: Pluto Pres.

Wallerstein, Immanuel. 1992. "The Concept of National Development, 1917 - 1989." American Behavioral Scientist, Vol 35 No. 4/5, March/June 1992. Sage Publications, Inc. 2003. The Decline of American Power. New York/London: The New Press. 2004. World Systems Analysis - An Introduction. Durham and London: Duke University Press.

Waltz, Kenneth N. 2000. "Structural Realism after the Cold War." International Security, Vol. 25, No. 1. (Summer, 2000), pp. 5-41

Watson, Roland. 2005. Bush selects Iraq war architect to be new head of World Bank. The Times, March 17, 2005. Retrieved on December 8, 2007. (http://www.timesonline.co.uk/article/0,,11069-1528465,00.html)

WFP. 2006. "Facts \& Figures." World Food Programme. Retrieved June 8, 2007. (http://www.wfp.org/aboutwfp/facts/hunger_facts.asp)

Wood, Ellen M. 1999. Kosovo and the New Imperialism. Monthly Review, Volume 51. $\begin{array}{llllll}\text { Number } 2 . & \text { Retrieved on }\end{array}$ (http://www.monthlyreview.org/699wood.htm)

World Bank. 1993. "The making of the East Asia Miracle." World Bank Policy Research Bulletin. August - October 1993, Volume 4, Number 4.

2003. "Breaking the Conflict Trap: Civil War and Development Policy." World Bank. Oxford University Press. . 2004. "Making Services Work for Poor People". World Development Report (WDR) 2004. 
2005. "Low-Income Countries Under stress: Update. Operations Policy and Country Services, 2005." World Bank. Retrieved on December 8, 2007.

(http://wwwwds.worldbank.org/servlet/WDSContentServer/WDSP/IB/2005/12/22/00 0090341_20051222092710/Rendered/PDF/34789.pdf)

. 2006a. History of the World Bank. World Bank. Retrieved on December 8, 2007. (http://web.worldbank.org/WBSITE/EXTERNAL/EXTABOUTUS/0,,contentMDK:2 0653660 menuPK:72312 pagePK:51123644 piPK:329829 theSitePK:29708,00.ht $\mathrm{ml})$

. 2006b. "Poverty Reduction Strategies." Povertynet, World Bank. Retrieved on December 8, 2007.

(http://web.worldbank.org/WBSITE/EXTERNAL/TOPICS/EXTPOVERTY/EXTPR S/0,,menuPK:384207 pagePK:149018 piPK:149093 theSitePK:384201,00.html)

2006c. Fragile States: The LICUS Initiative. World Bank. Retrieved December 8, 2007.

(http://web.worldbank.org/WBSITE/EXTERNAL/NEWS/0,,contentMDK:20127382

$\sim$ menuPK:34480 pagePK:34370 theSitePK:4607,00.html)

. 2006d. World Bank Senior Country Officer for Liberia, Luigi Giovine. Interview recorded July 15 and July 18, 2006 in Monrovia by Hahn N. (nsc.hahn@ gmail.com).

WTO. 2006. World Trade Organisation - The multilateral trading system - past, present and future. Retrieved on December 8, 2007.

(http://www.wto.org/english/thewto_e/whatis_e/inbrief_e/inbr01_e.htm) 